San Jose State University

SJSU ScholarWorks

Master's Theses

Master's Theses and Graduate Research

Spring 2012

\title{
Effects of a Virtually Abroad Program on Students' Cross-Cultural Competence
}

Emalynn Lucie Robinson

San Jose State University

Follow this and additional works at: https://scholarworks.sjsu.edu/etd_theses

\section{Recommended Citation}

Robinson, Emalynn Lucie, "Effects of a Virtually Abroad Program on Students' Cross-Cultural Competence" (2012). Master's Theses. 4168.

DOI: https://doi.org/10.31979/etd.ybpf-xnq9

https://scholarworks.sjsu.edu/etd_theses/4168

This Thesis is brought to you for free and open access by the Master's Theses and Graduate Research at SJSU ScholarWorks. It has been accepted for inclusion in Master's Theses by an authorized administrator of SJSU ScholarWorks. For more information, please contact scholarworks@sjsu.edu. 
EFFECTS OF A VIRTUALLY ABROAD PROGRAM ON STUDENTS' CROSS-CULTURAL COMPETENCE

\author{
A Thesis \\ Presented to \\ The Faculty of the Department of Psychology Studies \\ San José State University \\ In Partial Fulfillment \\ of the Requirements for the Degree \\ Master of Science
}

by

Emalynn L. Robinson

May 2012 
(C) 2012

Emalynn L. Robinson

ALL RIGHTS RESERVED 
The Designated Thesis Committee Approves the Thesis Titled

EFFECTS OF A VIRTUALLY ABROAD PROGRAM ON STUDENT CROSS-

CULTURAL COMPETENCE

by

Emalynn L. Robinson

APPROVED FOR THE DEPARTMENT OF PSYCHOLOGY

SAN JOSÉ STATE UNIVERSITY

May 2012

Dr. Sharon Glazer Department of Psychology

Dr. Joyce Osland Department of Organization and Management

Dr. Carolina Moliner Departamento de Psicología Social, and Research

Institute in Human Resources Psychology,

Organizational Development and Quality of Working

Life (IDOCAL), Universidad de Valencia 


\section{ABSTRACT \\ EFFECTS OF A VIRTUALLY ABROAD PROGRAM ON STUDENTS' \\ CROSS-CULTURAL COMPETENCE}

By Emalynn L. Robinson

A program-long, longitudinal, self-report study was conducted to assess the benefits and effects of student engagement in a five-week virtual team project, called the Virtually Abroad Program (VAP). The VAP required two or three students from each country to work together as a team on a course project. Students completed questionnaires at the start (Time 1) and end (Time 2) of the project. Study variables included culture-general knowledge, culture-specific knowledge, openness to new cultural experiences, and overall program evaluation. From Time 1 to Time 2, both types of knowledge increased significantly for the U.S. sample but not for the sample from Spain. Findings also revealed that controlling for country, a high self-reported score on culture-general knowledge at Time 1 and an increase in culture-general knowledge each positively related to an overall positive evaluation of the program, which was assessed at Time 2. Openness to new cultural experiences positively related to overall program evaluation too. Analyses failed to show support for openness to new experiences as a moderator of the relationships between culture-general knowledge at Time 1 and Time 2 nor culture-specific knowledge at Time 1 and Time 2 . Results from this study suggest that a VAP has utility and benefits for Organizational Psychology and Human Resources professionals. 


\section{ACKNOWLEDGEMENTS}

I would like to express my sincere appreciation to Dr. Sharon Glazer, who has been my mentor, professor, and guide throughout my graduate school experience. Her dedication and continued guidance, in spite of a transcontinental relocation, has been instrumental to my success. I would also like to thank Dr. Joyce Osland, who has offered wonderful insight from a business perspective. Her extensive knowledge in cultural communication and global leadership has been essential to rounding out my thesis. It has been a pleasure working for and with Dr. Osland on this and her own research. Dr. Carolina Moliner has also been a strong contributor to my research, both in implementing the VAP and providing guidance writing my thesis. I am grateful for the opportunity to have also met her in person in Spain in 2011.

In addition to my thesis committee, I also would like to extend my gratitude to Jeff Picaman, whose invaluable help as a research assistant allowed us to complete the data collection and entry. Jessica Simons, whose library research skills are amazing, continually supported me in literature searches and weekend writing sessions. My deep appreciation also extends to my parents, Kem and Sylvie Robinson, for their continued support throughout my graduate school journey, as well as their guidance in editing this paper. Finally, Eduardo de Jesus has been a continuous support for me from the beginning of my graduate career and I am fortunate to have his continued encouragement. 


\section{TABLE OF CONTENTS}

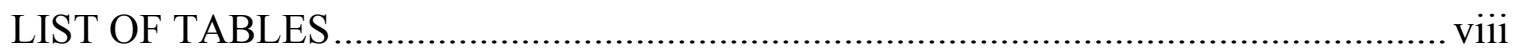

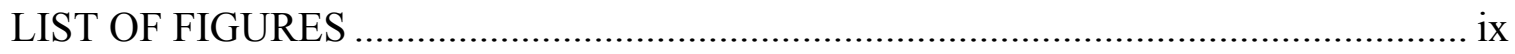

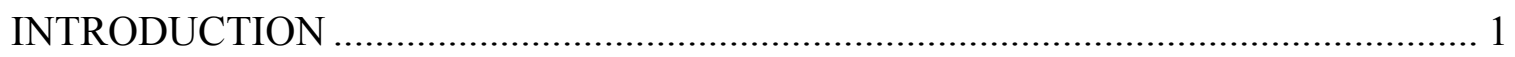

Cross-Cultural and Industrial/Organizational Psychology Education ............................ 2

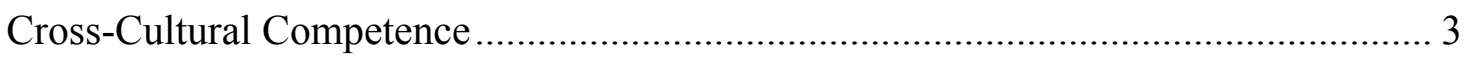

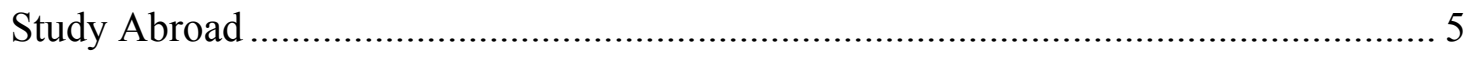

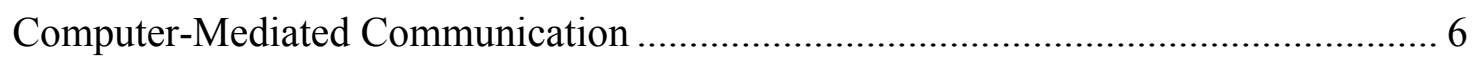

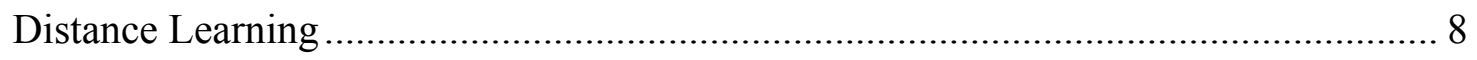

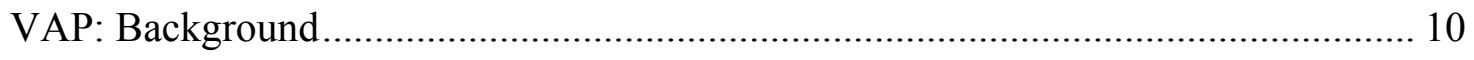

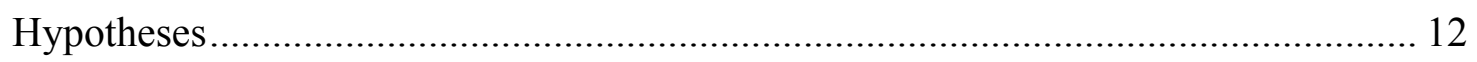

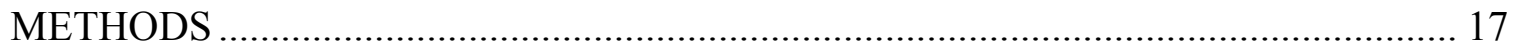

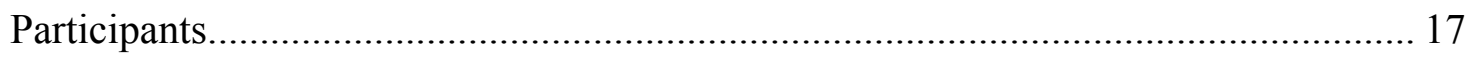

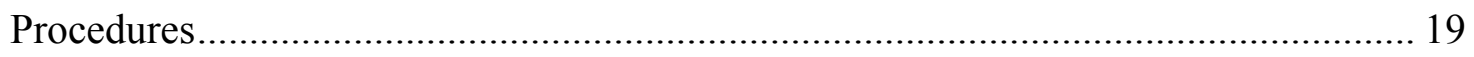

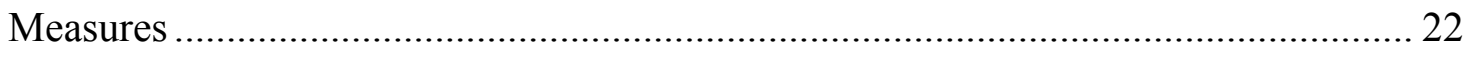

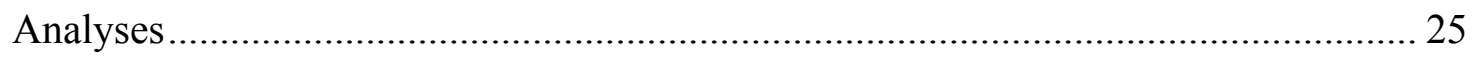

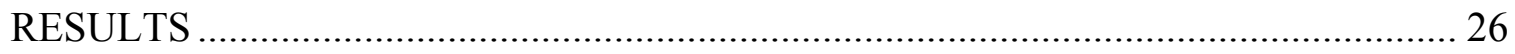

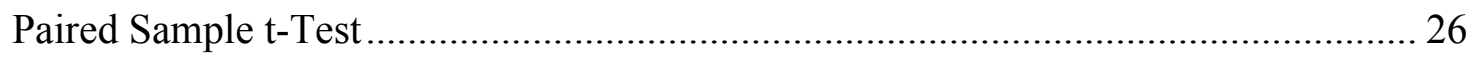

Country Differences in Cross-Cultural Knowledge Changes from T1 and T2 ........... 26

Regression of Cross-cultural Knowledge on Project Evaluation.................................... 29

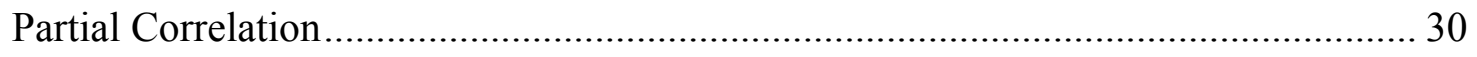


Effects of the Interaction of Cross-Cultural Knowledge at T1 and Openness to New Cultural Experiences on Cross-Cultural Knowledge at T2 .................................... 31

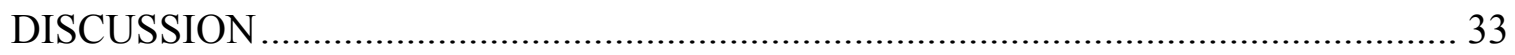

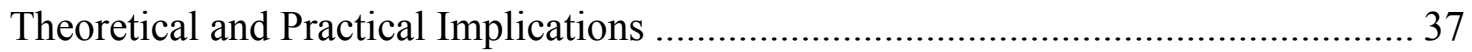

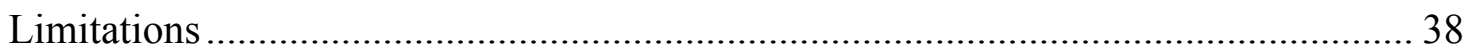

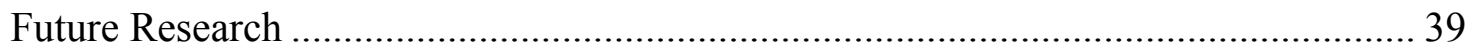

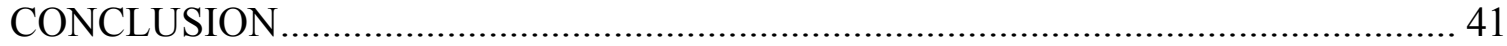

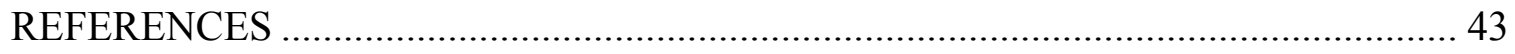

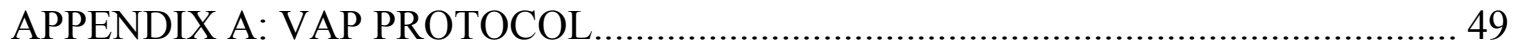

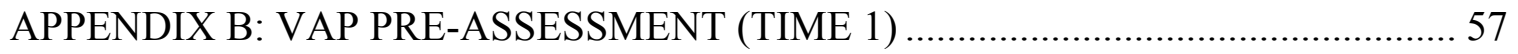

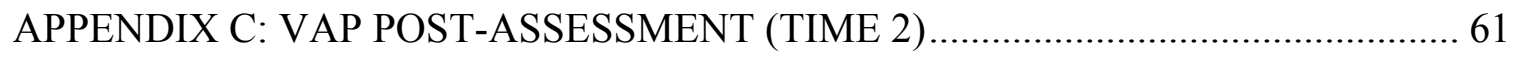




\section{LIST OF TABLES}

TABLE 1: Nationality of Participants by Country of Study............................................. 18

TABLE 2: Means, Standard Deviations, Reliabilities, and Correlations among Study Variables for USA (lower left diagonal) and Spain (upper right diagonal).... 27

TABLE 3: Correlations among Study Variables, Controlling for Country ....................... 28

TABLE 4: Interaction of Cross Cultural Knowledge (T1) and (T2) ............................. 29

TABLE 5: Project Evaluation Regressed on Culture-General Knowledge and Culture-

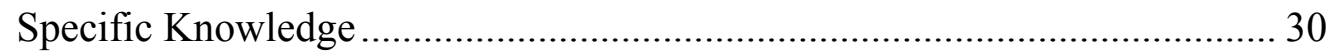

TABLE 6: Interaction of Cross Cultural Knowledge and Openness to New Cultural

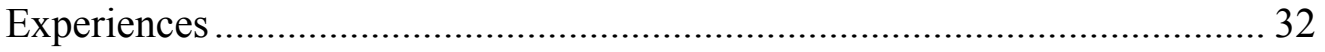

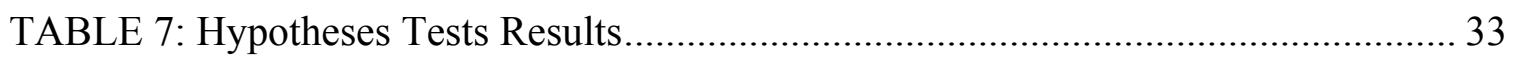




\section{LIST OF FIGURES}

FIGURE 1: VAP Timeline: Visual of program and process from week 1 to week $9 \ldots \ldots . . .12$ 


\section{Introduction}

Global virtual teams (GVTs) are a growing trend as more companies are encouraging this form of global interaction. Instead of sending employees abroad, GVTs save time and money, increase productivity and improve the quality of work life (Anonymous, 2001; Chen \& Nath, 2008; Gaspar, 2001). In this study, I conceptualize a GVT as a temporary work group composed of people who coordinate and execute a work project across time zones and national geographic boundaries through the use of information and communication technology (Glazer, Shargo, Trice, DaPonte, \& Marquez, 2009). GVTs benefit companies because they lower the cost of travel and allow employees with required skills and capabilities to work with each other despite geographical dispersion. Employees collaborate with people across the world at the same time, without the stress or financial burden of travel. The quality of work life can be

greatly improved using GVTs provided that the team members have a strong identity as a team and build collaborative trust (Chen \& Nath, 2008; Mulki, Locander, Mairshall, Harris, \& Hensel, 2008). Leaders can serve as key contributors to building team unity and creating trust that strengthens the capabilities of GVTs and their effectiveness (Joshi, Lazarova, \& Liao, 2006).

One of the challenges that face contributors of GVTs is limited intercultural interaction and time management training in preparation for and during the interaction of the team. For this reason, it is essential that universities begin preparing students not only with the knowledge and skills to carry out work-related technical tasks, but also with the ability to interact with people around the globe via computer-mediated interactions. 
GVT interactions with students from another country provide students with an experience similar to studying abroad, without physically moving abroad. They provide students with a safe environment in which to experience virtual teamwork, learn to cope with the challenges, reap the benefits, and learn strategies to cope with the challenge. In this thesis, I study how the combination of an experiential and didactic five-week GVT project focused on cross-cultural issues in Industrial/Organizational (I/O) Psychology improved student participants' cross-cultural competence.

The remaining sections of this literature review are organized as follow. First, I describe the significance of this study for developing I/O psychology programs and practitioners. Second, I describe what it means to have cross-cultural competence and ways of developing it. Third, I summarize research on virtual teams, specifically GVTs, and provide support for its utility in providing an international education. Fourth, I provide contextual background for the current study, as well as the approach used to implement a GVT project. This is followed by a summary of the study variables and justification for studying those variables, as well as the research hypotheses. The method section will describe the student sample, measures employed, and procedures for collecting data. Next I present results, discuss findings in relation to the literature, list limitations, and provide suggestions for future research.

\section{Cross-Cultural and Industrial/Organizational Psychology Education}

As companies expand their businesses across the world, demand for Industrial/Organizational (I/O) psychologists trained in a global I/O issues grows too. In particular, there is an increasing need to develop cross-cultural awareness, understanding, 
and skills (Triandis, 2006). I/O psychologists can use their background in organizational behaviors as informed by cross-cultural psychological principles to aid global businesses and their employees with intercultural work activities, policies, and practices. Thus, it is imperative to develop an international focus to I/O psychology graduates' curricula (Griffith \& Wang, 2010) so that internal and external I/O psychology consultants provide sage and correct guidance to companies. I/O psychology programs that want to internationalize their curricula and produce graduates who can help global workforce, can learn from other university international and study abroad programs, as well as from global training programs developed by organizations such as the Peace Corps (Sinangil \& Ones, 2001). Such international programs have been successful in aiding the development of students' and volunteers' cross-cultural competence. However, organizations currently seek to bring in incumbents ready to take on work that includes intercultural interactions. Pressure is put on university programs to provide and prepare the workforce of the future to meet industry demands.

\section{Cross-Cultural Competence}

The basis of this research relies on several frameworks to describe the nature and importance of cross-cultural competence (sometimes referred to as cultural intelligence and intercultural competence; Hammer, Bennett, \& Wiseman, 2003; Ng, Van Dyne, \& Ang, 2009). This paper applies Abbe, Gulick, and Herman's (2007) framework and definition for cross-cultural competence (3C), described as the knowledge, skills, and affect or motivation that allow individuals to adapt effectively in culturally complex environments. The above conceptualization of $3 \mathrm{C}$ shares similar properties with the 
definition of cultural intelligence. $\mathrm{Ng}$ et al. (2009) conceptualize cultural intelligence as an individual's capacity to effectively function in culturally diverse environments. Within the context of international organizations, 3C involves drawing on knowledge, personal attributes, and skills to perform effectively when working with people from different cultural backgrounds or in different cultural settings (Johnson, Lenartowicz, \& Apud, 2006). Abbe and colleagues' definition (2007) states that knowledge, skills and affect or motivation, as components of $3 \mathrm{C}$, can develop through training, education, and experience.

Knowledge signifies cultural awareness or understanding of other cultures and people from those cultures (Johnston, Paris, Wisecarver, Ferro, \& Hope, 2011). Working in unknown situations with people from unfamiliar cultures requires a high degree of cognitive complexity to comprehend and navigate effectively through the new situation. Knowing how to deal with ambiguity is considered a component of $3 \mathrm{C}$ (Abbe et al., 2007).

Examples of 3C skills include flexibility, self-regulation, and cultural interpersonal interactions. Flexibility in this context refers to the skill of adapting one's own behaviors in accord with various difficult and ambiguous situations. Self-regulation is a coping skill that refers to one's abilities to regulate his or her own emotions in relation to the situation and manage different stressors (Bar-On, Maree, \& Elias, 2007; Ciarrochi \& Mayer, 2007). Cross-cultural interpersonal interactions refer to skills in maintaining relationships and communicating effectively in intercultural encounters (Abbe et al., 2007). 
Affect and motivation refer to attitudes and desire to empathize with others. In order to work effectively with members of other cultures one should have an open and positive attitude about working in an unknown situation (McCloskey, Behymer, Papautsky, Ross, \& Abbe, 2010). Developing 3C also requires the ability to empathize with people from different cultures. People should understand others' points of view, as well as others' needs and emotions.

\section{Study Abroad}

Past research demonstrates that undergraduate students experiencing a study abroad program benefit from their exposure to cultures and development of cross-cultural knowledge, skills, and abilities (Marcottea, Desrochesb, \& Poupartb, 2007; Pedersen, 2010). For example, Kitsantas (2004), in a study of 232 U.S. study abroad students, who traveled to England, Italy, Greece, France, and Spain, found that study abroad programs enhance students' cross-cultural skills and global understanding. This was observed using pre- and post- self-report inventories, including the Cross-Cultural Adaptability inventory, the study Abroad Goal Scales, and the Global Perspective survey. The current study uses scales that measure constructs in a similar way. However, Pedersen found that an academic year-long study abroad program in England is not enough to develop intercultural competence. Her study showed that students who traveled abroad and received intercultural effectiveness and diversity training (i.e., intervention) developed much greater intercultural competence than students who only traveled abroad, but did not receive training and the control group (i.e., students who expressed interest in participating in the same study abroad program the following year, and thus did not 
travel). Results suggest that study abroad is in itself good in comparison with no international experience, but not sufficient for demonstrating significant gains in intercultural development. Intercultural training and guidance from an instructor positively affect students' intercultural growth.

Unfortunately, studying abroad is not always financially or logistically feasible. Likewise, many companies today are cutting costs associated with international travel and expecting their employees to be able to interact with people worldwide through computer-mediated communication. For these reasons, the International Programs Office of the presents study's U.S. university developed a "virtually abroad program" (VAP). The virtual learning environment allows students to meet and exchange ideas and work, independent of space and time constraints (Akar, Öztürk, Tunçer, \& Wiethoff, 2004). The VAP offers an opportunity to participate in a virtual team and reap the benefits of less travel and lower cost, with more timing flexibility. However, the VAP also offers an opportunity for students in the program to interact with members of different cultures. Through repeated interactions with people from different cultures, students' $3 \mathrm{C}$ develops too. The VAP, therefore, creates a virtual, intercultural distance learning experience through computer-mediated communication, but without the added expenses of study abroad. In the next section, I describe computer-mediated communication and distance learning programs.

\section{Computer-Mediated Communication}

According to Johnson, Bettenhausen, and Gibbons (2009), a virtual team must use some type of computer-mediated communication (CMC). There are varying degrees of 
the extent to which a team is considered virtual. For the purposes of this research, we operationalize the virtual team as one in which at least one other team member is geographically dispersed and all team members are interacting through synchronous or asynchronous modes of computer-mediated communication (Glazer et al., 2009; Prasad \& Akhilesh, 2002; Wigand, Picot, \& Reichwald, 1997).

The use of $\mathrm{CMC}$ affects the quality of the message transmission, according to Daft and Lengel's (1986) Media Richness Theory. The theory states that the message that is conveyed is affected by the methods used. Methods with fewer nonverbal communication cues and limitations on the interactions can cause ambiguity in the message. High equivocality occurs least during face-to-face interactions and more often in other methods of communication. Online communication through text chatting and email, as used in the VAP, would be considered less rich than face-to-face interaction because of the limited facial and nonverbal cues. The theory states that there will be more ambiguity and communication breakdowns with methods used that are not mediarich. Tasks with complex decisions and planning would be considered less effective using $\mathrm{CMC}$, such as online chatting. In the present study, live video conferencing was used to present the final projects of the VAP. This form of media would be considered richer because of the visual and audio cues that occur in real time. This would be closer to the richness of having face-to-face interactions (Daft \& Lengel, 1986; Han, Hiltz, Fjermestad, \& Wang, 2011).

The current study used online chatting and emails, which is not considered as media rich as face-to-face interaction. However, online chatting and emails used for past 
virtual teams required more precise, active, descriptive and positive interaction. This is in comparison to, face-to-face interaction, in order to accomplish team project goals. Direct communication in these cases aided in breaking down cultural barriers between GVT members (Osland et al., 2004). Online chatting and emails, as part of CMC, have also been used for educational purposes, including distance learning.

\section{Distance Learning}

Distance education does not significantly differ from a classroom setting in terms of learning outcomes and evaluation (Arbaugh, 2000). In some cases, the asynchronous learning involved in distance education had a slightly better effect on learning (Allen, Mabry, Mattrey, Bourhais, Titsworth, \& Burrell, 2004; Spooner, Jordan, Algozzine \& Spooner, 1999) and was evaluated more positively by students (Eppler \& Ironsmith, 2004). The learning process involved in distance programs affects the attitudes of students involved in distance learning projects.

Bernard and colleagues (2009) found that students working in a collaborative virtual environment have more positive attitudes and evaluations regarding online programs than students working in programs focused on student-teacher interaction or student-content interaction. This is where the student-content interaction programs specifically use written information provided virtually, without interaction with other

people. A collaborative work environment involves students working together as a team virtually to complete projects. The authors also argued that student interactions and working in teams lead to better learning and more positive program evaluations because students learn through each other and their team setting. Moreover, programs that are 
centered on the use of problem-based learning strategies, involving asynchronous, computer-mediated communication and instruction, resulted in higher levels of positive attitudes (Bernard et al., 2004). However, such positive experiences are not the rule.

$\operatorname{Ke}$ (2010) found that the most difficult part of the distance learning experience was the collaboration involved with virtual teamwork on a class project. Ke indicated that students reported a preference to work individually due to the additional challenges involved in coordinating team interactions virtually. Working in a virtual team was seen as less efficient and less effective. Likewise, Johnson and colleagues (2009) found that working in a virtual environment can lead to negative attitudes and affect toward the organization. They surmise this may be due to fewer nonverbal cues and limited social interaction outside the task at hand. In global virtual team projects, problems related to differing cultural backgrounds and native language challenges might also complicate the program's success (Akar et al., 2004). In other words, in GVTs a major hurdle may be lack of 3C. Despite these challenges, Akar and colleagues concluded, students enjoyed generating concepts and collaborating in virtual groups across cultures.

To summarize, given: (1) the importance of a cross-cultural experience, (2) the limitations of a poor global economy, and (3) the need to prepare the future workforce for virtual communication with people from different countries, the "Virtually Abroad Program" (VAP) was developed. The present study capitalized on the opportunity to evaluate the success of such a program by studying the extent to which students' knowledge increased for the duration of the program. 


\section{VAP: Background}

In 2009, a major public university in the west of the United States of America (USA) developed the VAP program to encourage international interactions among students and faculty vís à vís computer-mediated study experiences. The VAP was created as an alternative option to physically studying abroad. It was expected to provide students with opportunities to develop skills in working with people from national cultures other than their own, without the cost involved with travel.

The VAP evaluated in the present research required undergraduate students studying in two countries, the United States and Spain, to work together in 4-5 person teams composed of 2-3 students from each country. The course material involved a didactic component of learning (i.e., lecture and reading) and an experiential component (i.e., interacting with teammates through computer-mediated modes of communication to complete an assigned project). The project entailed learning about an organizational psychology concept through the lenses of people coming from Spain and the United States, as well as one other country of choice where the team members had not visited before (and with concurrence from professors).

Students interacted through use of asynchronous and collaborative learning supplemented by classroom, in-person learning. With guidance from Jarvenpaa and Leidner's (1999) findings that suggested ways of building and maintaining trust, the VAP unfolded in a purposeful manner in which first the students were instructed to socialize and discuss hypothetical situations. The scenarios did not have right or wrong answers, but presented personality and cultural differences between students that became clear if 
responses were fully discussed. This step was important for developing trust through informal social interactions that were unrelated to the required tasks on which final team performance would be evaluated. It further helped pave the way to finding commonalities, which supports group connectedness. Further, as past studies have shown that physically seeing teammates is an important predictor of trust, which is also an important component for successful team performance (Holton, 2001; Scott, Castañeda, Quick, \& Linney, 2009), this VAP encouraged the use of Skype for video chatting. It was not required and, as later found, most students did not use it, and relied on chat rooms and emails, including Skype and a virtual conferencing program used from the University from Spain. Course instructors required students to send to them carbon copies of all of their team and project-related email communications. At the start of the VAP, all students were required to exchange photos. Student teams were asked to create an expatriate training guide for a chosen third country. Finally, by the end of the VAP, to enhance the experience of working collaboratively, all members of each team, together delivered their PowerPoint presentations through video conferencing software (see figure $1)$. 


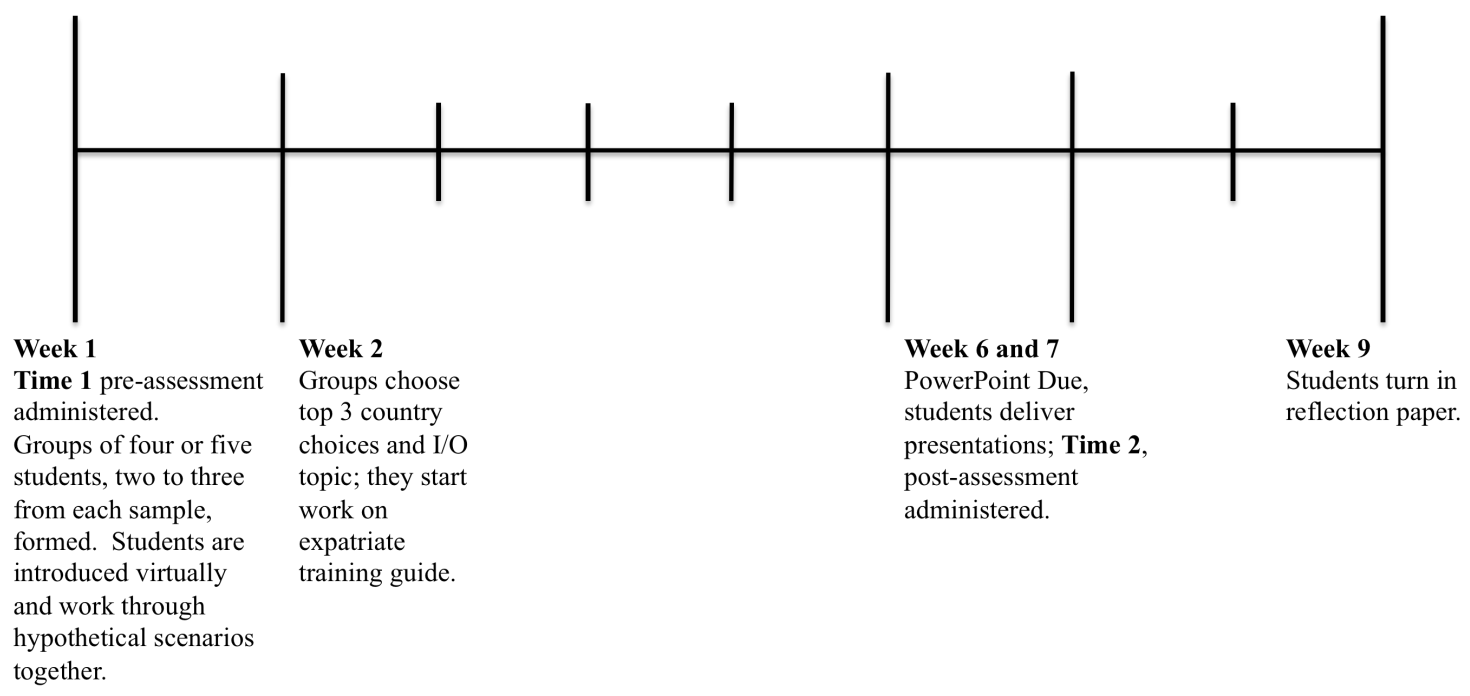

Figure 1. VAP Timeline: Visual of program and process from week 1 to week 9.

\section{Hypotheses}

In order to evaluate students' $3 \mathrm{C}$ development and the utility of the VAP for student learning, the following variables were assessed and the following hypotheses posed.

Cross-cultural knowledge. This research measures knowledge in terms of understanding the complexities of learning about culture and understanding cultural similarities and differences. Cross-cultural teamwork is not sufficient for developing an understanding of cultural differences. It is also important to investigate the different cultures and study factors that influence cultures in general. Cross-cultural knowledge is conceptualized as awareness of how to engage in cross-cultural interactions. The VAP reinforced cross-cultural knowledge development by requiring students to engage with peers from another country while also studying about culture in general and a specific $\left(3^{\text {rd }}\right)$ national culture (the team chose to study). In this way, students developed both culture-general and culture-specific knowledge (Imahori \& Lanigan, 1989). 
Culture-general knowledge consists of an understanding of cultural differences. This knowledge focuses on how to operate across several different cultures, as opposed to one single cultural context. Also included in the concept of culture-general is the understanding of the components of culture, cultural values, and frameworks for comparing different cultures.

Culture-specific knowledge focuses on specific information about another culture including law, history, and customs. This type of knowledge does not include the individual's own thought process and understanding of the cultural differences that exist between one's own culture and others. The central idea is knowing specific information about one single culture to eventually adapt better to operating within the culture (Johnson et al., 2009).

The present research examines changes in culture-general and culture-specific knowledge as a result of participating in the VAP. Students from both countries interacted with people from cultures that differed from their own, as well as learned about a culture other than their own and their teammates.

Hypothesis 1: Participants from both countries will increase their (a) culturegeneral and (b) culture-specific knowledge from $\mathrm{T} 1$ to $\mathrm{T} 2$.

Despite the gains in cross-cultural knowledge, it is important to consider that the U.S. students in the present study registered for a capstone psychology course and only upon entering the classroom did most of the students learn that the course is on crosscultural organizational psychology and involved a virtual learning component. In contrast, the VAP students studying in Spain were among hundreds of students in an 
Introduction to I/O Psychology course. The VAP students from Spain, however, knowingly volunteered to partake in the VAP and had an average to above average knowledge of English. They did not receive any compensation for participating and did so for the experience. The VAP students in Spain, therefore, might have already had higher levels of openness to cultural experiences and cross-cultural knowledge than the U.S. students. For this reason:

Hypothesis 1c: Gains in U.S. students' culture-general and culture-specific knowledge each will be greater than gains in Spanish students' cross-cultural knowledge.

Program evaluation. In order to determine if the VAP resulted in a positive learning and overall experience, students responded to an attitudinal question about the VAPs' benefits. Previous research shows that asynchronous distance learning yields positive evaluations and attitudes towards the experience (Bernard et al, 2009; Eppler \& Ironsmith, 2004). Thus, as students gain in cross-cultural (general and specific) knowledge their VAP evaluation will be more favorable. More specifically,

Hypothesis 2a:

(i) Culture-general knowledge at $\mathrm{T} 1$ will positively relate with program evaluation at $\mathrm{T} 2$.

(ii) Culture-general knowledge at T2, after controlling for culture-general knowledge at $\mathrm{T} 1$, will positively relate with program evaluation at $\mathrm{T} 2$.

Hypothesis $2 b$ :

(i) Culture-specific knowledge at $\mathrm{T} 1$ will positively relate with program evaluation at $\mathrm{T} 2$. 
(ii) Culture-specific knowledge at T2 after controlling for culture-specific knowledge at $\mathrm{T} 1$ will positively relate with program evaluation at $\mathrm{T} 2$.

Openness to new cultural experiences. Similar to McCrae's (1994) definition of openness, this study operationalizes openness as a stable personality trait and is depicted as an attitude toward accepting and inviting new possibilities and adventures in life. Interviews by McCloskey and colleagues (2010) of U.S. Army service members revealed that openness was the second highest rated personal approach needed to demonstrate $3 \mathrm{C}$.

Nesdale and Todd (2000) facilitated an intervention on intercultural contact with Australian (domestic) and international residents of one student dormitory in an Australian university but not in another (in the same university, i.e., the control). The researchers found that, although the intervention was effective in increasing intercultural contact, intercultural knowledge and openness to cultural experiences affected the extent to which the intervention was helpful for increasing intercultural contact among Australian (but not international) students. Contemplating why such a result was not found for the international students too, the authors concluded that the international students might have already had high levels of openness to cultural experiences and cultural knowledge that led them to choose studying abroad.

On the basis of the above findings, it is expected that the more open students will be to the VAP experience, the higher their program evaluation ratings. In other words, students who have higher scores on openness would likely report greater benefits from participating in the VAP than students low on openness. On the basis of the above, I 
expect that students with higher levels of openness to cultural experiences would most likely rate the program more favorably than students who were low on openness to cultural experiences.

Hypothesis 3: A higher score on openness to new cultural experiences at T1 will positively relate with program evaluation at $\mathrm{T} 2$.

Openness to new experiences is important to culture-general knowledge.

Individuals high on openness to new experience are more likely to seek out new cultural experience and learn about culture from other people. Individuals who are more open to international and cultural experiences will reduce their ethnocentrism and increase their knowledge of other cultures (Caligiuri \& Tarique, 2011). Thus, I expect openness to be an important factor in the increase in culture-general knowledge from $\mathrm{T} 1$ to $\mathrm{T} 2$.

Hypothesis 4a: Openness to new cultural experiences at T1 will moderate the relationship between culture-general knowledge at $\mathrm{T} 1$ and culture-general knowledge at $\mathrm{T} 2$.

Hypothesis $4 b$ : Openness to new cultural experiences at $\mathrm{T} 1$ will moderate the relationship between culture-specific knowledge at $\mathrm{T} 1$ and culture-specific knowledge at $\mathrm{T} 2$. 


\section{Methods}

\section{Participants}

The population from which the study sample was drawn is undergraduate students from two large public universities: one in Spain and one in California, USA. The U.S. university is racially diverse: African-American 3.83\%, Asian students $29.94 \%$, Hispanic $20.68 \%$, White $27.23 \%$, and Other $10.03 \%$. In addition, $8 \%$ of the student population is international. Despite the ethnic and racial diversity of the population of students enrolled at the U.S. university, most of its students do not choose to gain international experiences through study abroad (Office of Institutional Research, 2011). The sample reflects, in part, the population diversity $(n=25)$. Based on the numbers in Table 1 , at least one-third of the U.S. students were of Asian background (consistent with the population of students on the U.S. university's student population). Using a question that

only asked for student nationality, the survey did not address ethnic or racial background. Therefore, it is impossible to provide any other clear indication of ethnicity for the 15 who marked themselves as American.

The Spanish university is not as ethnically diverse as the U.S. university. Its student population consists of $93 \%$ students of Spanish nationality (Servei d'Anàlisis i Planificació, 2011). The Spanish university’s sample $(n=28)$ is more diverse, since only $75 \%$ of the students in the sample were of Spanish nationality. 
Table 1

Nationality of Participants by Country of Study

Nationality Frequency

\begin{tabular}{|c|c|}
\hline \multicolumn{2}{|c|}{ United States $(n=25)$} \\
\hline American & 15 \\
\hline Spanish & 1 \\
\hline Indian & 2 \\
\hline Chinese & 1 \\
\hline Japanese & 1 \\
\hline Taiwanese & 1 \\
\hline Vietnamese & 3 \\
\hline Fijian & 1 \\
\hline \multicolumn{2}{|c|}{ Spain $(n=28)$} \\
\hline Colombian & 1 \\
\hline Belgian & 2 \\
\hline Dutch & 1 \\
\hline German & 1 \\
\hline Romanian & 1 \\
\hline Spanish & 21 \\
\hline Spanish/Venezuelan & 1 \\
\hline
\end{tabular}

Participants ranged in ages from 20 to 37 years of age $(M=23.40, S D=3.20)$. Among the participant sample, the group from Spain had 6 males and 21 females, whereas the U.S. class had 20 females and 5 males. Most of the students from both groups were Psychology majors. Participants from the U.S. class were studying in a capstone course that covered cross-cultural organizational psychology, whereas the students from Spain were enrolled in an introduction to I/O psychology class. Students in the United States were required to participate in the VAP as part of their final course grade. In Spain, students of I/O psychology were recruited from several introductory I/O psychology classes and informed about the VAP. Students were required to demonstrate proficiency with the English language and interest in participating in the VAP 
experience, without receipt of any tangible rewards. They were selected through an application and interview process.

The Spanish students applied directly to be part of the program. In contrast, the U.S. students were not aware of the course topic and methodology and they had little choice but to remain because the course was required for graduation and the activity was required in partial fulfillment of class requirements.

\section{Procedures}

Four faculty members from different disciplines in the U.S. university were awarded a small grant to develop VAPs in which their students would study with students in different countries for a period of a few weeks to an entire semester. For the current study, I focus on the VAP program developed by a faculty member of the psychology department for her psychology students taking their capstone psychology course (i.e., culminating psychology course for their Bachelors degree in psychology).

In this program, students from two classes, one in Spain and one in the United States, participated in the VAP for 5 weeks. All of the students were assigned to one of 12 Teams. Teams were composed of two to three students from each country, and teams consisted of between four and five students. During week one, students were introduced to their team members and were required to participate in a "getting acquainted" activity where they discussed their responses to two hypothetical scenarios, each containing forced response choices. The goal of the activity was to get students to open up, learn about their teammates, and, because there were no right or wrong answers to the scenario questions, think about personality and cultural differences. 
For weeks two through five, each team selected a country of study that was unfamiliar to each of the members', meaning none of the team members had visited the "third" country or had family background rooted in the chosen country. The students were then required to participate in a minimum of weekly chats and document all chats and emails in order to complete the assignment. Project requirements included working together as a team to create a training guide for expatriates traveling to the selected country (see Appendix A for more information on this course's VAP protocol). Each team's training guides focused on a unique I/O Psychology-related topic, for example Negotiation and Teams in Egypt, Motivation and Satisfaction in Germany, and Occupational Stress in Brazil. To gain a cultural perspective of the chosen country, students were also asked to make a comparison between the country in which they currently lived (in Spain or the United States) and the "third" country. During week five, students synchronously delivered their presentations to the entire group using videoconferencing.

In order to assess the impact of the program on the students' learning, the students completed a pre-assessment (T1) survey of 42 items during the first week of the program and a post-assessment survey (T2) of 129 items after the program, during week six. Students in the United States completed a pen and paper version during class times. In order to maintain confidentiality, the students placed their completed survey in a sealed envelope and wrote a unique color code name (e.g., Pinkalicious or Wild wild berry) randomly picked and assigned. This allowed the course instructor to ensure all students completed the surveys, without linking the names of the students to their surveys. In 
order to ensure that the U.S. students did not forget their unique color code, students sealed their color code in an envelope, wrote their names on the front of the envelope and signed across the flap as evidence of no tampering with envelopes. When T2 survey was administered, students received their sealed envelopes, opened them, and retrieved their unique color code to label T2 survey. For the class in Spain, students completed two Word document surveys distributed to them via email by their course instructor. Students created unique codes by writing their father's and mother's full initials. Both unique codes were used to match surveys from $\mathrm{T} 1$ and $\mathrm{T} 2$. One student from the U.S. sample and another from the Spanish sample did not complete their T2 surveys. Only their T1 surveys were collected.

The current research utilizes a self-report survey format in order to ensure participants of complete anonymity. For this reason and the sake of increasing veracity of self-reported data, no other source was tapped for data on the students (e.g., students' grades). Although there has been controversy over the method, Spector (1994) maintains its utility if the intended constructs are defined and measured properly. Moreover, longitudinal research design using self-report, as opposed to cross-sectional designs, allows for more causal inferences. The present study employs a longitudinal design (see Figure 1) with an initial evaluation at Time 1 (T1; week one of the project) and a followup evaluation at Time 2 (T2; at completion of the presentations in the USA and one week post presentations in Spain), as recommended to assess change (Rohs, Langone, \& Coleman, 2001). Though some self-report studies fail to show strong validity, measures that are considered more objective, such as physiological measures, show similar 
problems. Such objective measures have difficulty demonstrating validity, more specifically, criterion validity (Howard, 1994). An example of a study where self-report research failed to show strong validity is in the case of Taylor, Lamers, Vincent, and O’Driscoll (1998), in which a longitudinal research design was used to assess through self-report, respondents' learning. There were weak correlations within subjects from Time 1 to Time 2 - the time lapsed between the beginning of the training course and the conclusion - as well as weak correlations across individuals between Time 1 and Time 2 . The researchers called for more specific, behavioral questions in questionnaires for future research and for addressing validity using multiple statistical methods. The questionnaire used in the current research poses behavioral questions to strengthen the validity.

\section{Measures}

As developed by Dr. Miriam Erez, the surveys used for both assessment periods employed a 7-point Likert-type scale and some open-ended, written questions. The T1 and T2 surveys are presented in Appendix B and Appendix C, respectively. All of the items assessed in the T1 survey were assessed again in the T2 survey, as well as additional program outcome items. Although the survey measured several variables, the current study focuses on four variables: culture-general knowledge, culture-specific knowledge, openness to new cultural experiences, and project evaluation. Items representing the four variables were rated solely on the Likert-type scale, ranging from 1, strongly disagree to 7 , strongly agree.

Cross-cultural knowledge. Four items specifically addressed culture-general knowledge (see Appendix B, section 2, items 1-4 and Appendix C, section 2, part D 
items 1-4), and six items specifically addressed culture-specific knowledge (see Appendix B, section 2, items 5-10 and Appendix C, section 2, part D items 5-10). Sample items for culture-general knowledge include "I am conscious of the cultural knowledge I use when interacting with people with different cultural backgrounds" and "I am conscious of the cultural knowledge I apply to cross-cultural interactions." Culturespecific knowledge examples include "I know the legal and economic systems of other cultures" and "I know the religious beliefs of other cultures." A higher value would indicate higher cross-cultural knowledge. The measures were reliable. Cronbach alphas were high at T1 and T2. Alphas for culture-general knowledge at T1 were $\alpha=.84$ for the U.S. sample and $\alpha=.82$ for the Spanish sample; at T2 they were $\alpha=.87$ for the U.S. sample and $\alpha=.91$ for the Spanish sample. Alphas for culture-specific knowledge at T1 were $\alpha=.88$ for the U.S. sample, $\alpha=.87$ for the Spanish sample. At T2 they were $\alpha=$ .91 for the U.S. sample and $\alpha=.88$ for the Spanish sample.

Further, with a few exceptions, most inter-item correlations were moderate to strong and supported the validity of the scale. At T1, the inter-item correlations among the culture-general knowledge items were between .27 and .79 for the U.S. sample and between .33 and .82 for the Spanish sample. At T2, the inter-item correlations among the culture-general knowledge items were between .45 and .74 for the U.S. sample, and between .68 and .87 for the Spanish sample. On culture-specific knowledge T1, interitem correlations were between .26 and .75 for the U.S. sample and between .15 and .74 for the Spanish sample. Inter-item correlations for the culture-specific knowledge items 
at T2 were between .16 and .89 for the U.S. sample and between .24 and .89 for the Spanish sample.

Openness to new cultural experiences. Six items were used to measure openness to new cultural experiences (see Appendix B, section 1, items 13-18 and Appendix C, section 2, part C, items 1-6). A sample item is "I am keen to learn from people who have different values or motivations." The measure showed internal consistency at $\alpha=.82$ for the U.S. sample and $\alpha=.67$ for the sample from Spain. The values for T2 were $\alpha=.84$ for the U.S. sample and $\alpha=.73$ for the sample from Spain. Additionally, the inter-item correlations for this variable were between .15 and .73 for the U.S. sample and between .02 and .72 for the Spanish sample. For T2, inter-item correlations ranged from .20 to .77 for the U.S. sample and from .04 to .69 for the Spanish sample. Low inter-item correlations suggest some items might not be good indicators of openness to new cultural experiences.

Project evaluation. Ten items were used to assess attitudes toward the VAP (see section 2, Part A, item 6. Part B, item 6, section 3, items 1-4, 8-10, and section 3, the open-ended section, item 5, Appendix C). Respondents indicated their overall feelings about the VAP, as well as the perceived impact from the program on their knowledge and personal growth. Sample items include "I personally gained knowledge about other cultures" and "I learned how to work effectively with members from other cultures.." This measure also showed high internal consistency, $\alpha=.91$ for the U.S. sample and $\alpha=$ .85 for the sample from Spain. Inter-item correlations ranged from .10 to .90 for the U.S. sample and .04 to .71 for the Spanish sample. 


\section{Analyses}

The current research assessed validity through inter-item correlations, within subjects correlations, and across subjects correlations. These validation procedures will demonstrate minimal impact from common method measurement (Spector, 2006). To test Hypotheses $1 \mathrm{a}$ and $1 \mathrm{~b}$, that participants from both countries increase their culturegeneral and culture-specific knowledge from T1 to T2, data were analyzed via paired sample $t$-tests to determine if a difference existed between the Spanish sample and the U.S. sample for the focal study variables at T1 and T2. Hypothesis 1c, that gains in U.S. students' culture-general and culture-specific knowledge will each be greater than gains in Spanish students' cross-cultural knowledge, was tested using a moderated regression analysis. For Hypothesis 2, that culture-general knowledge at T1 and T2 will positively relate with program evaluation at $\mathrm{T} 2$, and that culture-specific knowledge at $\mathrm{T} 1$ and $\mathrm{T} 2$ will positively relate with program evaluation at $\mathrm{T} 2$, a regression analysis was employed to assess how much variance was accounted for in project evaluation by cross-cultural knowledge at $\mathrm{T} 1$ and again at $\mathrm{T} 2$ after controlling for $\mathrm{T} 1$. To test Hypotheses 3 , that a higher score on openness to new cultural experiences at $\mathrm{T} 1$ will positively relate with program evaluation at T2, correlation analyses were employed. For Hypothesis 4, which states openness to new cultural experiences at $\mathrm{T} 1$ for culture-general and culture-specific knowledge will moderate the relationship between culture-general knowledge at T1 and culture-general knowledge at T2 and the same for culture-specific knowledge, a moderated regression analysis was employed, controlling for country. 


\section{Results}

Table 2 presents means, standard deviations, reliabilities, and correlations among study variables for the United States (lower diagonal) and Spain (upper right diagonal). Correlations among study variables, controlling for country, are presented in Table 3.

\section{Paired Sample t-Test}

Hypothesis 1a stated that participants from both countries will increase their culture-general knowledge from $\mathrm{T} 1$ to $\mathrm{T} 2$, while hypothesis $1 \mathrm{~b}$ stated participants from both countries will increase their culture-specific knowledge from T1 to T2. A paired sample $t$-test allowed for insight as to how self-reported cross-cultural knowledge changed from Time 1 to Time 2 for both samples. For the U.S. sample, both culturegeneral and culture-specific knowledge increased significantly $(t=-2.83, p<.05 ; t=$ $2.47, p<.05$, respectively). For the sample from Spain, mean scores on culture-general and culture-specific knowledge did not increase significantly, thus hypotheses $1 \mathrm{a}$ and $1 \mathrm{~b}$ are partially supported.

\section{Country Differences in Cross-Cultural Knowledge Changes from T1 and T2}

Hypothesis 1c stated that the U.S. students would have greater gains in culturegeneral and culture-specific knowledge from T1 to T2 than Spanish students. Using a moderated regression analysis, culture- general knowledge at T2 and culture- specific knowledge at T2 were each regressed on culture- general knowledge T1 and culturespecific knowledge $\mathrm{T} 1$, respectively, as well as country, followed by the interaction between the two knowledge domains at $\mathrm{T} 1$ and country. 
Table 2

Means, Standard Deviations, Reliabilities, and Correlations among Study Variables for USA (lower left diagonal) and Spain (upper right diagonal)

\begin{tabular}{|c|c|c|c|c|c|c|c|c|c|c|}
\hline Variable & M & SD & $\alpha$ & 1 & 2 & 3 & 4 & 5 & 6 & 7 \\
\hline Mean (M) & & & & 5.40 & 5.55 & 4.62 & 4.63 & 5.53 & 5.74 & 5.91 \\
\hline Standard Deviation (SD) & & & & .85 & .92 & .97 & 1.15 & .71 & .76 & .71 \\
\hline Reliability $(\alpha)$ & & & & .82 & .91 & .87 & .88 & .67 & .73 & .85 \\
\hline $\begin{array}{l}1 \text { Culture-General Knowledge } \\
\text { (T1) }\end{array}$ & 4.79 & 1.22 & .84 & -- & $.58 * *$ & $.67 * *$ & $.61^{* *}$ & $.66^{* *}$ & $.56^{* *}$ & $.53 * *$ \\
\hline $\begin{array}{l}2 \text { Culture-General Knowledge } \\
\text { (T2) }\end{array}$ & 5.49 & 1.00 & .87 & $.45^{*}$ & -- & .29 & $.44^{*}$ & $.51 * *$ & $.70 * *$ & $.45^{*}$ \\
\hline $\begin{array}{l}3 \text { Culture-Specific Knowledge } \\
\text { (T1) }\end{array}$ & 2.96 & 1.12 & .88 & $.48^{*}$ & .21 & -- & $.74 * *$ & $.54 * *$ & .16 & .32 \\
\hline $\begin{array}{l}4 \text { Culture-Specific Knowledge } \\
\text { (T2) }\end{array}$ & 3.46 & 1.17 & .91 & .16 & .35 & $.65^{* *}$ & -- & .38 & .20 & $.53 * *$ \\
\hline $\begin{array}{l}5 \text { Openness to New Cultural } \\
\text { Experiences (T1) }\end{array}$ & 5.24 & 0.95 & .82 & .36 & $.64^{* *}$ & .04 & .26 & -- & $.62 * *$ & .35 \\
\hline $\begin{array}{l}6 \text { Openness to New Cultural } \\
\text { Experiences (T2) }\end{array}$ & 5.36 & 0.93 & .84 & .28 & $.73 * *$ & .30 & $.42 *$ & $.72 * *$ & -- & $.40^{*}$ \\
\hline 7 Project Evaluation (T2) & 6.07 & 0.77 & .91 & .27 & $.67 * *$ & -.05 & -.02 & .39 & .34 & -- \\
\hline
\end{tabular}

Notes. ${ }^{*} p<.05 . * * p<.01$. 
Table 3

Correlations among Study Variables, Controlling for Country

\begin{tabular}{lcccccc}
\hline Variable & 1 & 2 & 3 & 4 & 5 & 6 \\
\hline 1 Culture-General Knowledge (T1) & -- & & & & & \\
2 Culture-General Knowledge (T2) & $.50^{* *}$ & -- & & & & \\
3 Culture-Specific Knowledge (T1) & $.55^{* *}$ & .25 & -- & & & \\
4 Culture-Specific Knowledge (T2) & $.35^{*}$ & $.40^{* *}$ & $.69^{* *}$ & -- & & \\
5 Openness to New Cultural & $.42^{* *}$ & $.58^{* *}$ & .25 & $.31^{*}$ & -- & \\
Experiences (T1) & & & & & & \\
6 Openness to New Cultural & $.44^{* *}$ & $.71^{* *}$ & .24 & $.31^{*}$ & $.68^{* *}$ & -- \\
Experiences (T2) & $.38^{* *}$ & $.56^{* *}$ & .12 & $.26 *$ & $.37^{*}$ & $.37^{*}$ \\
7 Project Evaluation (T2) & & & & & &
\end{tabular}

Further, a dummy-coded country variable $(\mathrm{USA}=0$, Spain $=1)$ was created to test the extent to which country influences these relationships. Results indicated that although country did not significantly interact with culture-general knowledge at $\mathrm{T} 1$ to affect culture-general knowledge at T2, the slope of culture-general knowledge gain for the American students (slope $=.64)$ was steeper than for the students from Spain (slope $=$ .37). Similar results were found with respect to changes in culture-specific knowledge, but the slopes were not as different between the countries (U.S. slope $=.87$ and Spanish slope $=.66)$. Thus, while the results were not statistically significant, they were in the hypothesized direction. 
Table 4

Interaction of Cross Cultural Knowledge (T1) and (T2)

\begin{tabular}{|c|c|c|c|c|c|c|}
\hline Variable & B & $\beta$ & $\begin{array}{c}F \\
\text { statistic }\end{array}$ & $R$ & $\Delta R^{2}$ & $\begin{array}{l}\mathrm{Adj} \\
R^{2}\end{array}$ \\
\hline \multicolumn{7}{|l|}{ DV $=$ Culture-General Knowledge T2 } \\
\hline Constant & 3.72 & & & & & \\
\hline Country (dummy coded) (a) & -1.60 & -.85 & .05 & .03 & .00 & -.02 \\
\hline $\begin{array}{l}\text { Culture-General Knowledge (T1) } \\
\text { (b) }\end{array}$ & .37 & $.42 *$ & $15.46 * *$ & .50 & $.25 * *$ & .22 \\
\hline $\mathrm{a} \times \mathrm{b}$ & .27 & .78 & 1.17 & .52 & .02 & .22 \\
\hline \multicolumn{7}{|l|}{$\mathrm{DV}=$ Culture-Specific Knowledge T2 } \\
\hline Constant & 1.49 & & & & & \\
\hline Country (dummy coded)(c) & -.89 & -.35 & $12.31 * *$ & .45 & $.20 * *$ & .19 \\
\hline $\begin{array}{l}\text { Culture-Specific Knowledge } \\
\text { (T1) (d) }\end{array}$ & .66 & $.68 * *$ & $42.37 * *$ & .76 & $.38 * *$ & .56 \\
\hline $\mathrm{c} x \mathrm{~d}$ & .21 & .40 & .79 & .77 & .01 & .56 \\
\hline
\end{tabular}

\section{Regression of Cross-cultural Knowledge on Project Evaluation}

Hypothesis 2a stated that (i) culture-general knowledge at $\mathrm{T} 1$ will positively relate with program evaluation at $\mathrm{T} 2$ and (ii) a significant increase in culture-general knowledge at T2 after controlling for culture-general knowledge at T1 will positively relate with program evaluation at T2. Hypothesis $2 \mathrm{~b}$ stated that (i) culture-specific knowledge at T1 will positively relate with program evaluation at $\mathrm{T} 2$ and (ii) a significant increase in culture-specific knowledge at T2 after controlling for culture-specific knowledge at T1 will positively relate with program evaluation at $\mathrm{T} 2$.

To assess Hypothesis 2, project evaluation was regressed on culture-general and culture-specific knowledge (see Table 5). Culture-general knowledge at T1 had a significant effect on project evaluation, $F(1,46)=7.55, p<.01$, as did culture-general 
knowledge at $\mathrm{T} 2$ significantly relate to project evaluation, $F(1,45)=12.20, p<.01$. The $R^{2}$ was .33 , indicating that culture-general knowledge accounted for a significant amount of the variance in project evaluation. However, culture-specific knowledge at $\mathrm{T} 1$ and at T2, did not relate to project evaluation. These results offer support for hypothesis $2 \mathrm{a}$, but not for hypothesis $2 b$.

\section{Table 5}

Project Evaluation Regressed on Culture-General Knowledge and Culture-Specific Knowledge

\begin{tabular}{|c|c|c|c|c|c|c|}
\hline Variable & $\mathrm{B}$ & $\beta$ & $\begin{array}{c}F \\
\text { statistic } \\
\end{array}$ & $\mathrm{R}$ & $\Delta R^{2}$ & $\operatorname{Adj} R^{2}$ \\
\hline \multicolumn{7}{|l|}{ Regression 1} \\
\hline Constant & 3.55 & & & & & \\
\hline Country (dummy coded) & -.24 & -.16 & .57 & .11 & .01 & -.01 \\
\hline CGK (T1) & .09 & .13 & $7.55 * *$ & .39 & .14 & .11 \\
\hline CGK (T2) & .38 & $.49 * *$ & $12.20 * *$ & .58 & .33 & .29 \\
\hline \multicolumn{7}{|l|}{ Regression 2} \\
\hline Constant & 5.56 & & & & & \\
\hline Country (dummy coded) & -.24 & -.16 & .43 & .09 & .01 & -.01 \\
\hline CSK (T1) & -.09 & -.17 & .52 & .14 & .01 & -.02 \\
\hline CSK (T2) & .22 & .38 & 3.03 & .28 & .06 & .02 \\
\hline
\end{tabular}

\section{Partial Correlation}

Hypothesis 3 stated that a higher openness to new cultural experiences at T1 will positively relate with program evaluation at T2. A partial correlation, controlling for country, was employed to determine the extent to which openness to new cultural 
experiences (T1) correlated with program evaluation. The partial correlation was significant $(r=.37, p<.01)$, thus, offering support for hypothesis 3 .

\section{Effects of the Interaction of Cross-Cultural Knowledge at T1 and Openness to New Cultural Experiences on Cross-Cultural Knowledge at T2}

Hypothesis $4 \mathrm{a}$ stated that openness to new cultural experiences at $\mathrm{T} 1$ will moderate the relationship between culture-general knowledge at T1 and culture-general knowledge at T2. Hypothesis $4 \mathrm{~b}$ stated that Openness to new cultural experiences at $\mathrm{T} 1$ will moderate the relationship between culture-specific knowledge at T1 and culturespecific knowledge at T2. To test these hypotheses, culture-general knowledge at T2 was regressed on culture-general knowledge at T1, openness to new experience (T1), and the interaction between culture-general knowledge (T1) and openness to new experiences (T1).

The total variance in culture-general knowledge at T2 accounted for by the country of study was $0 \%$, indicating country did not strongly affect culture-general knowledge at T2. Culture-general knowledge at T1 and openness to new experiences (T1), as main effects, accounted for a total of $42 \%$ of the variance and were significant ( $p$ $<.01)$. The interaction of the main effect variables, however, did not account for any additional variance in culture-general knowledge at T2 (see Table 6). Thus, Hypothesis 4a was not supported.

The total variance in culture-specific knowledge at T2 accounted for by dummycoded country was a significant $20 \%(p<.01)$. The main effect variables, culturespecific knowledge at $\mathrm{T} 1$ and openness to new cultural experiences (T1), accounted for 
an additional significant $39 \%(p<.01)$ of variance in culture-specific knowledge at $\mathrm{T} 2$, but the interaction terms did not account for any additional variance in culture-specific knowledge (T2). Hypothesis 4b, therefore, was also not supported.

Table 6

Interaction of Cross Cultural Knowledge and Openness to New Cultural Experiences

\begin{tabular}{|c|c|c|c|c|c|c|}
\hline Variable & $\mathrm{B}$ & $\beta$ & $F$ statistic & $R$ & $\Delta R^{2}$ & $\begin{array}{l}\mathrm{Adj} \\
R^{2}\end{array}$ \\
\hline \multicolumn{7}{|l|}{$\mathrm{DV}=$ Culture-General Knowledge T2 } \\
\hline Constant & .21 & & & & & \\
\hline Country (dummy coded) & -.25 & -.13 & .05 & .03 & .00 & -.02 \\
\hline $\begin{array}{l}\text { Culture-General Knowledge (T1) } \\
\text { (a) }\end{array}$ & .51 & .58 & & & & \\
\hline $\begin{array}{l}\text { Openness to New Cultural } \\
\text { Experiences }(\mathrm{T} 1)(\mathrm{b})\end{array}$ & .76 & .67 & $16.00 * *$ & .65 & $.42 * *$ & .38 \\
\hline $\mathrm{a} \times \mathrm{b}$ & -.05 & -.40 & .13 & .65 & .00 & .36 \\
\hline \multicolumn{7}{|l|}{ DV $=$ Culture-Specific Knowledge T2 } \\
\hline Constant & -.65 & & & & & \\
\hline Country (dummy coded) & -.06 & -.02 & $12.31 * *$ & .45 & $.20 * *$ & .19 \\
\hline $\begin{array}{l}\text { Culture-Specific Knowledge } \\
\text { (T1) (c) }\end{array}$ & .97 & 1.01 & & & & \\
\hline $\begin{array}{l}\text { Openness to New Cultural } \\
\text { Experiences }(\mathrm{T} 1)(\mathrm{d})\end{array}$ & .37 & .24 & $22.58 * *$ & .77 & $.39 * *$ & .57 \\
\hline $\mathrm{c} \times \mathrm{d}$ & -.05 & -.32 & .21 & .78 & .00 & .56 \\
\hline
\end{tabular}




\section{Discussion}

The present study aimed to assess the effects of a VAP on development of both culture-specific and culture-general knowledge. The goals of this study included evaluating the benefits and challenges of a VAP and reinforcing a unique, new program to apply to GVT literature. Table 7 displays results of hypotheses tested.

Table 7

Hypotheses Tests Results

\begin{tabular}{cc} 
Hypothesis & Result \\
\hline $1 \mathrm{a}$ & Partially Supported \\
$1 \mathrm{~b}$ & Partially Supported \\
$1 \mathrm{c}$ & Partially Supported \\
$2 \mathrm{a}$ & Supported \\
$2 \mathrm{~b}$ & Not Supported \\
3 & Supported \\
$4 \mathrm{a}$ & Not Supported \\
$4 \mathrm{~b}$ & Not Supported \\
\hline
\end{tabular}

This study demonstrated that students from the United States, but not from Spain, increased their culture-general and culture-specific knowledge. Hypotheses 1a and 1b were partially supported in that culture-general knowledge increased significantly for the U.S. sample; however, the hypotheses were not supported for the sample from Spain. One explanation for this finding is that the students from the sample from Spain volunteered to be part of their class, knowing they would participate in the VAP. This type of recruiting for the class may have attracted students who already had high crosscultural general and specific knowledge. The two samples had two different types of motivation: the U.S. sample may have approached the VAP as an opportunity to learn as 
part of a class, while the sample from Spain may have been motivated by the opportunity to have the experience to be in a GVT. The difference in motivation could have accounted for the difference in learning with the two samples.

As shown in Pedersen's (2010) study, international students with higher levels of 3C were attracted to the study-abroad program. In contrast, the students from the U.S. sample did not know in advance that, in choosing to take the class, they would be participating in the VAP. They had lower self-reported cross-cultural knowledge in the beginning of the program than the students in the sample from Spain, and some even commented how uncomfortable they felt realizing how little they knew. Many of the students from Spain were also international students, who spoke multiple languages, as was the case with students who studied abroad and chose cross-cultural programs (Pedersen, 2010). This might have increased the likelihood of the students from Spain having higher cross-cultural knowledge at the start of the program. However, in the U.S. student sample, there were at least three known international students. Another plausible explanation is that people in Europe generally have a greater awareness of different cultures than Americans; many European countries are surrounded by culturally and linguistically different neighbors (Ginsburgh \& Prieto-Rodriguez, 2011).

The study also showed that culture-general knowledge and a significant increase in culture-general knowledge positively related to a higher project evaluation (Hypotheses 1c). However, results of the study did not indicate the same relationship for culture-specific knowledge. 
The results showed support for Hypothesis 2a but not for 2b. Culture-general knowledge had a significant effect on project evaluation as well as a positive, significant relationship (H2a). This indicates that a self-reported change in culture-general knowledge yielded more positive project evaluations. Implications of this finding might be that, if students or professionals are able to develop more culture-general knowledge, they might have a better overall feeling about the international projects in which they will they participate.

GVT projects that encourage participants to increase their culture-general knowledge may result in better outcomes for the project and the participants overall because they may feel more positively about the experience and, therefore, more motivated. Likewise, as the cross-cultural organizational psychology course was set up to teach about cross-cultural issues and to debrief on the VAP every week, improvements for U.S. but not Spanish students might be a reflection of the instructor's method for understanding the interactions (Pedersen, 2010). This also serves as an explanation behind the partial support for hypothesis 1c, that the students from the U.S. sample would see greater gains in both types of cross-cultural knowledge from T1 to T2.

In contrast, there was no significant relationship between culture-specific knowledge and project evaluation ( $\mathrm{H} 2 \mathrm{~b})$. An explanation may be that the students were focused on creating a project together and did not have enough exposure to the individual aspects of each other's cultures. This did not allow them to develop the knowledge specific to each culture, such as laws and customs that could have been learned when physically traveling to the other country. 
Findings from the study also demonstrated that openness to new cross-cultural experiences positively related to program evaluation. Hypothesis 3 was supported by the strong, significant and positive relationship between openness to new cultural experiences (T1) and program evaluation. This suggests that people who were more open to new cultural experiences were more likely to feel positively and benefit from the experience.

According to Nesdale and Todd (2000), students who experienced the facilitated version of their own study's international program and were higher in openness spent more time talking to other students and making connections to students from other cultures. As openness to new cultural experiences is an essential part of $3 \mathrm{C}$, students in the present study who initially were more open were also more likely to perceive a benefit from the experience and further increase their cross-cultural competence. Increased motivation and openness is also related to better results and higher ratings of other educational programs (Murphy \& Rodríguez-Manzanares, 2009; Raman \& Pashupati, 2002).

The study did not show that openness to new cultural experiences moderated the relationship between both types of cross-cultural knowledge. Analyses testing Hypotheses $4 \mathrm{a}$ and $4 \mathrm{~b}$ showed that openness to new cultural experiences (T1) did not have a significant moderating effect on changes in culture-general knowledge or culturespecific knowledge from T1 to T2. However, openness to new experiences significantly related to both types of knowledge at T2 and with culture-general knowledge at T1. Further post-hoc analyses to test Hypothesis 4a showed, for the U.S. sample a positive 
significant relationship between culture-general knowledge at $\mathrm{T} 1$ and $\mathrm{T} 2$, and people with higher openness (T1) and higher culture-general knowledge at Time 1 had higher Time 2 scores. This indicates that for the U.S. students, overall culture-general knowledge increased from Time 1 to Time 2, and openness to new cultural experiences was related; however, openness did not moderate the relationship.

Correlation analyses of the study variables by country indicated more positive, strong, and significant correlations for culture-general knowledge at $\mathrm{T} 1$ and $\mathrm{T} 2$ for the sample from Spain (with the exception of culture-specific knowledge at T1) when compared with the correlations of the same variables in the U.S. sample. The U.S. sample showed fewer strong and significant correlations among variable constructs overall, when compared with the sample from Spain.

Findings indicate that students from Spain who reported high levels of openness to new cultural experiences also reported having a high level of culture-general knowledge at T1 and T2. Culture-specific knowledge (T1) had the weakest correlations with the other variable constructs, as it was only strongly related to culture-specific knowledge at $\mathrm{T} 2$ and the relationships with other variable constructs were nonsignificant. This may indicate that culture-specific knowledge was not as important. It had the weakest relationships with the other measures.

\section{Theoretical and Practical Implications}

Culture-general knowledge increased significantly for the U.S. sample and slightly for the sample from Spain. The findings also demonstrated that culture-general knowledge was related to project evaluation. By working with people from other 
cultures, students may have learned cultural rules that reach across contexts. Culturespecific knowledge did not increase for the sample from Spain and was not related to project evaluation. This might mean the students did not learn the individual aspects of U.S. or Spanish culture, such as laws and behaviors. Perhaps more time or more exposure to the individual cultures would be required to see a difference. However, the students did learn how to work together in a broader context of people from other cultures and about a third national culture in which none of the team members have lived or visited. Thus, the students also developed culture-general knowledge through learning about other cultures for their project. Culture-specific knowledge may need to be increased through longer exposure to the different culture and/or a modified team assignment. A medium that also uses more feedback, with higher contact and media rich could have more impact (Daft \& Lengel, 1986).

The VAP can have positive learning effects and development for students in terms of developing culture-general knowledge, but more research should be done to investigate how culture-specific knowledge may be increased through distance learning. Aspects of 3C can be developed through VAP; however, more research should be conducted to see what other aspects of $3 \mathrm{C}$ can be used and increased through distance learning programs.

\section{Limitations}

Limitations to this study include the fact that both samples were not recruited the same way. The students from Spain may have already had greater $3 \mathrm{C}$ as they might have 
been drawn to the class for the opportunity to partake in the VAP experience. This could have influenced the samples to have different starting levels of cross-cultural knowledge.

Another limitation is that self-report is the only method used to collect data. This method was employed in order to preserve the anonymity of the participants, particularly as the threat to anonymity is higher when the sample size is smaller and the data collector worked closely with the course instructor. Cross-cultural knowledge changes were not measured by a grade or test. They were only measured through behavioral self-report questions. Statistical validity was established through various measures to address this issue. However, the small sample size might have made it more difficult to obtain statistically significant results.

Additionally, there was no control group or comparison groups to the VAP groups, such as groups that never participated in international programs or groups that physically studied abroad. Such comparisons could reveal specific benefits that are unique to a virtual program for cross-cultural competence.

\section{Future Research}

Future research should consider various types of samples. Larger sample sizes that go beyond the academic world and extend to multinational organizations would provide interesting comparisons and reveal more areas to understand in developing crosscultural competence. Comparing GVTs in businesses to teams in which people travel abroad could also yield beneficial results to further understanding the development of $3 \mathrm{C}$.

Another area of future research might be in the various aspects of $3 \mathrm{C}$. Other aspects of KSAAs, such skills and abilities, not just knowledge, which was tested in the 
present study, may be interesting to observe in GVTs. It may be interesting as well to compare 3C to the ENOP model of Work, Organizational and Personnel (WOP) Psychologists. The ENOP models describes professional and research competencies as essential for the WOP psychologist and 3C is an example of such a competency (ENOP, 1998). Skills such as communication could be tested to see if they can be affected through virtual communication.

Moreover, future research should take into consideration the extent to which participants have had international experiences and cross-cultural education. One might expect that $3 \mathrm{C}$ would develop more strongly for those without prior experiences and education than for those with, as the greatest strides in development should be from no knowledge to some knowledge, particularly at basic education levels. One research approach might be to have one group of students of the same course (different course sections) receive cross-cultural education before the VAP and another group receive cross-cultural education after the VAP (or not at all), while also assessing students' past experiences to determine if any gains in $3 \mathrm{C}$ were made over the course of the VAP.

Another variable of interest to study is type of information computer technology used to interact with others throughout the globe. Future studies could compare the utility of using different modes of virtual interactions including phone, video conferencing, email, instant messaging, and chat rooms. Comparing these modes of communication might reveal which modes yield better performance outcomes and development of $3 \mathrm{C}$. 


\section{Conclusion}

Cross-cultural competence is made up of several distinct variables, two of which are knowledge and openness to new situations. This study showed that a virtual, asynchronous distance-learning program affected development of culture-general knowledge, but openness to new situations did not aid in that knowledge development. Findings of this study add to GVT literature by providing evidence that the VAP helps students develop aspects of $3 \mathrm{C}$, even in a short amount of time. Virtual teams offer an alternative to physical travel. Though VAPs cannot replace living abroad, they may be useful for educational and business purposes in developing certain aspects of $3 \mathrm{C}$. This type of training may be used to help workers and students develop culture-general knowledge that will be vital in developing relationships with members of other cultures and strengthening intercultural business associations. Developing culture-general knowledge will allow individuals to transfer their learning to various situations involving interactions with people from various cultures. This would be most useful for students and professionals involved in international business that would require cross-cultural interactions with varying cultures. Programs, such as the VAP, can help individuals develop knowledge essential to having successful interactions with members of other cultures.

Similar VAPs with other countries and other groups of students can be used to benefit students in I/O psychology. Students can learn culture-general and culturespecific knowledge to prepare for working with members of other cultures, both virtually and in person. VAPs can help students and emerging professionals prepare for 
international work, by allowing them to develop teamwork skills, exposing them to new cultures and the challenges this exposure brings, and preparing them for future GVTs in their workplaces. I/O professionals can have better success when working with international customers with better 3C (Griffith \& Wang, 2010). Finally, VAPs are a cost-effective way to help prepare students for the challenges facing them in the today's global economy. 


\section{References}

Abbe, A., Gulick, L. M. V., \& Herman, J. L. (2007). Cross-cultural competence in army leaders: A conceptual and empirical foundation. Arlington, VA: US Army, Research Institute for the Behavioral and Social Sciences. Retrieved from http://search.ebscohost.com/login.aspx?direct=true\&db=pxh\&AN=551892009001\&site=ehost-live; http://www.hqda.army.mil/ari/

Akar, E., Öztürk, E., Tunçer, B., \& Wiethoff, M. (2004). Evaluation of a collaborative virtual learning environment. Education \& Training, 46(6-7), 343-352. doi:10.1108/00400910410555259

Allen, M., Mabry, E., Mattrey, M., Bourhais, J., Titsworth, S., \& Burrell, N. (2004). Evaluating the effectiveness of distance learning: A comparison using metaanalysis. Journal of Communication, 54(3), 402-420. doi:10.1111/j.14602466.2004.tb02636.x

Anonymous (2001). WorldCom study shows virtual work emerges as a prominent trend in the American workforce. New York: PR Newswire Association LLC. Retrieved from http://search.proquest.com/docview/449210626?accountid=10361

Arbaugh, J. B. (2000). Virtual classroom versus physical classroom: An exploratory study of class discussion patterns and student learning in an asynchronous internet-based MBA course. Journal of Management Education, 24(2), 213-33. Retrieved from http://search.ebscohost.com/login.aspx?direct=true \&db= eric\&AN=EJ600787\&site=ehost-live

Bar-On, R., Maree, J., \& Elias, M. (Eds.). (2007). Educating people to be emotionally intelligent. Westport, CT: Praeger Publishers/Greenwood Publishing Group.

Bernard, R. M., Abrami, P. C., Borokhovski, E., Wade, C. A., Tamim, R. M., Surkes, M. A., \& Bethel, E. C. (2009). A meta-analysis of three types of interaction treatments in distance education. Review of Educational Research, 79(3), 12431289. doi:10.3102/0034654309333844

Bernard, R. M., Abrami, P. C., Lou, Y., Borokhovski, E., Wade, A., Wozney, L., et al. (2004). How does distance education compare with classroom instruction? A meta-analysis of the empirical literature. Review of Educational Research, 74(3), 379-439. doi:10.3102/00346543074003379 
Caligiuri, P., \& Tarique, I. (2011). Dynamic competencies and performance of global leaders: The role of personality and developmental experiences, SHRM Foundation Research, (2011, January 31). General Format. Retrieved from www.shrm.org/about/foundation/research/Documents/Caligiuri\%20\%20Tarique\% 20Final\%20Report\%202-11.docx.

Chen, L., \& Nath, R. (2008). A socio-technical perspective of mobile work. Information Knowledge Systems Management, 7(1/2), 41-60.

Ciarrochi, J., \& Mayer, J. D. (2007). The key ingredients of emotional intelligence interventions: Similarities and differences. In J. D. Mayer (Ed.), Applying emotional intelligence: A practitioner's guide (pp. 144-156). New York: Psychology Press.

Daft, R. L., \& Lengel, R. H. (1986). Organizational information requirements, media richness and structural design. Management Science, 32(5), 554-571. Retrieved fromhttp://search.ebscohost.com.libaccess.sjlibrary.org/login.aspx?direct=true\&d $\mathrm{b}=\mathrm{bth} \& \mathrm{AN}=7020553 \&$ site $=$ ehost-live

ENOP (1998). European curriculum in work and organizational psychology. Reference model and minimal standards. Paris: ENOP/Maison des Sciences de l'Homme.

Eppler, M. A., \& Ironsmith, M. (2004). PSI and distance learning in a developmental psychology course. Teaching of Psychology, 31(2), 131-134.

Gaspar, S. (2001, September). Virtual teams, real benefits. Network World, 18(39), 4545. Retrieved from http://search.proquest.com/docview/215967344?accountid=10361

Ginsburgh, V. A., \& Prieto-Rodriguez, J. (2011). Returns to foreign languages of native workers in the European Union. Industrial \& Labor Relations Review, 64(3), 599618.

Glazer, S., Shargo, I., Trice, B., DaPonte, M., \& Marquez, B. (2009). Global virtual teams and work-related stress: Implications of culturally different communication styles through computer-mediated communication. Unpublished manuscript.

Griffith, R. L., \& Wang, M. (2010). The Internationalization of I-O Psychology: We're not in Kansas anymore... The Industrial-Organizational Psychologist, 48(1), 4146. Retrieved from http://siop.org/tip/july10/481_features.pdf\#page=41 
Hammer, M. R., Bennett, M. J., \& Wiseman, R. (2003). Measuring intercultural sensitivity: The intercultural development inventory, international journal of intercultural relations. International Journal of Intercultural Relations, 27, 421.

Han, H., Hiltz, S. R., Fjermestad, J. \& Wang, Y. (2011). Does medium matter? A comparison of initial meeting, IEE Transactions on Professional Communication, 54(4), 376-391. doi: 10.1109/TPC.2011.2175759

Holton, J. (2001). Building trust and collaboration in a virtual team. Team Performance Management, 7(3), 36-47. Retrieved from http://search.proquest.com/docview/217102531?accountid=10361

Howard, G. S. (1994). Why do people say nasty things about self-reports? Journal of Organizational Behavior, 15(5), 399-404. doi:10.1002/job.4030150505

Imahori, T. T. \& Lanigan, M. L., (1989). Relational model of intercultural communication competence', International Journal of Intercultural Relations 13(3), 387-428.

Jarvenpaa, S. L., \& Leidner, D. E. (1999). Communication and trust in global virtual teams. Organization Science, 10(6), 791-815. doi:10.1287/orsc.10.6.791

Johnson, J. P., Lenartowicz, T., \& Apud, S. (2006). Cross-cultural competence in international business: Toward a definition and a model. Journal of International Business Studies, 37(4), 525-543. Retrieved from http://search.ebscohost.com/login.aspx?direct=true\&db=bth\&AN=21766910\&site $=$ ehost-live

Johnson, S. K., Bettenhausen, K., \& Gibbons, E. (2009). Realities of working in virtual teams: Affective and attitudinal outcomes of using computer-mediated communication. Small Group Research, 40(6), 623-649. doi:10.1177/1046496409346448

Johnston, J., Paris, C., Wisecarver, M., Ferro, G., \& Hope, T. (2011). A framework for cross-cultural competence \& learning recommendations. Paper presented at the $H S C B$, Chantilly, VA.

Joshi, A., Lazarova, M. B., \& Liao, H. (2006). A cross-level study of identification in geographically dispersed teams: The role of leadership, Academy Of Management Annual Meeting Proceedings, D1-D6. doi:10.5465/AMBPP.2006.22898623 
Ke, F. (2010). Examining online teaching, cognitive, and social presence for adult students. Computers \& Education, 55(2), 808-820.

doi:10.1016/j.compedu.2010.03.013

Kitsantas, A. (2004). Studying abroad: The role of college student's goals on the development of cross-cultural skills and global understanding. College Student Journal, 38(3), 441-452. Retrieved from

http://search.ebscohost.com/login.aspx?direct=true\&db=psyh\&AN=2004-19149016\&site $=$ ehost-live

Marcottea, C., Desrochesb, J., \& Poupartb, I. (2007). Preparing internationally minded business graduates: The role of international mobility programs. International Journal of Intercultural Relations, 31, 655-666.

McCloskey, M. J., Behymer, K. J., Papautsky, E. L., Ross, K. G., \& Abbe, A. (2010). A developmental model of cross-cultural competence at the tactical level. (Technical Report No. 1278). Arlington, VA: United States Army Research Institute for the Behavioral and Social Sciences.

McCrae, R. R. (1994). Openness to experience: Expanding the boundaries of factor V. European Journal of Personality, 8(4), 251-272. doi:10.1002/per.2410080404

Mulki, J., Locander, W. B., Mairshall, G. W., Harris, E. G., \& Hensel, J. (2008). Workplace isolation, salesperson commitment, and job performance. Journal of Personal Selling \& Sales Management, 28(1), 67-78.

Murphy, E., \& Rodríguez-Manzanares, M. A. (2009). Teachers' perspectives on motivation in high school distance education. Journal Of Distance Education, 23(3), 1-24.

Nesdale, D., \& Todd, P. (2000). Effect of contact on intercultural acceptance: A field study. International Journal of Intercultural Relations, 24(3), 341-360. doi:10.1016/S0147-1767(00)00005-5

Ng, K., Van Dyne, L., \& Ang, S. (2009). From experience to experiential learning: Cultural intelligence as a learning capability for global leader development. Academy of Management Learning \& Education, 8(4), 511-526. Retrieved from http://search.ebscohost.com/login.aspx?direct=true \&db=psyh\&AN=2010-00338$003 \&$ site $=$ ehost-live

Office of Institutional Research, San Jose State University. (2011). Long-term trends by ethnicity. San Jose, CA. Retrieved from: http://www.oir.sjsu.edu/cognos8/cgibin/cognos.cgi 
Osland, J., Bird, A., Maznevski, M., Scholz, C., McNett, J., Mendenhall, M., Stein, V. \& Weyer, D. (2004). Global reality with virtual teams: Lessons from the geographically distant multicultural teams project. In C. Wankel \& R. DeFillippi (Eds.) The Cutting Edge of International Management Education, (Vol. 2), (115141). Greenwich, CT: Information Age Publishing.

Pedersen, P. J. (2010). Assessing intercultural effectiveness outcomes in a year-long study abroad program. International Journal of Intercultural Relations, 34, 70-80.

Prasad, K., \& Akhilesh, K. (2002). Global virtual teams: What impacts their design and performance? Emerald Group Publishing, Limited. Retrieved from http://search.proquest.com/docview/217112622? accountid=10361

Raman, P., \& Pashupati, K. (2002). Turning good citizens into even better ones: The impact of program characteristics and motivations on service learning outcomes. Journal of Nonprofit \& Public Sector Marketing, 10(2), 187-206. doi:10.1300/J054v10n02_11

Rohs, F. R., Langone, C. A., \& Coleman, R. K. (2001). Response shift bias: A problem in evaluating nutrition training using self-report measures. Journal of Nutrition Education, 33(3), 165-170. doi:10.1016/S1499-4046(06)60187-5

Scott, P., Castañeda, L., Quick, K., \& Linney, J. (2009). Synchronous symmetrical support: A naturalistic study of live online peer-to-peer learning via software videoconferencing. Interactive Learning Environments, 17(2), 119-134. doi:10.1080/10494820701794730

Servei d'Anàlisis i Planificació, (2011). Recull de dades Estadístiques. Valencia, Spain.

Sinangil, H. K., \& Ones, D. S. (2001). Expatriate management. In N. Anderson, D. S. Ones, H. Kepir Sinangil \& C. Viswesvaran (Eds.), Handbook of Industrial, Work, and Organizational Psychology 1,424-443. London, UK: Sage.

Spector, P. E. (1994). Using self-report questionnaires in OB research: A comment on the use of a controversial method. Journal of Organizational Behavior, 15(5), 385392. doi:10.1002/job.4030150503

Spector, P. E. (2006). Method variance in organizational research: Truth or urban legend? Organizational Research Methods, 9(2), 221-232. doi:10.1177/1094428105284955 
Spooner, F., Jordan, L., Algozzine, B., \& Spooner, M. (1999). Student ratings of instruction in distance learning and on-campus classes. Journal of Educational Research, 92(3), 132-140. doi:10.1080/00220679909597588

Taylor, P. J., Lamers, A., Vincent, M. P., \& O'Driscoll, M. P. (1998). The validity of immediate and delayed self-reports in training evaluation: An exploratory field study. Applied Psychology: An International Review, 47(4), 459-479. doi:10.1111/j.1464-0597.1998.tb00038.x

Triandis, H. C. (2006). Cultural intelligence in organizations. Group \& Organization Management, 31(1), 20-26. doi:10.1177/1059601105275253

Wigand, R., Picot, A., \& Reichwald, R. (1997). Information, organization and management: Expanding markets and corporate boundaries. Chichester, England: Wiley. 


\section{Appendix A: VAP Protocol}

\section{Virtually Abroad Program Team Project \\ Instructions for participants \\ October-December 2009}

\section{Welcome to the Virtually Abroad Program Team Project (VAPTP)}

The goal of this project is to give you an opportunity to experience working in multicultural teams on a joint project with students from another country. This is an online environment that allows cross-cultural teams to cooperate on joint projects and monitor their interaction patterns.

In the current project, you will have the opportunity to work in teams with students studying in Spain and USA.

\section{Learning Objectives:}

-Experience collaboration with others in a virtual setting.

-To obtain international exposure by work with people from different countries.

-Learning about different cultures by:

-social and academic interactions with students from another country

-studying culture characteristics of a country that none of the students have ever been exposed to before forming teams

The information below, describes

(1) The project assignments and grading.

(2) Communication means in the project.

(3) Time table and time differences.

We suggest that you read everything carefully before the project starts.

All this information, appear also in the project site.

Project coordinator for USA: Sharon Glazer: sharon.glazer@sjsu.edu

Project coordinator for Spain: Carolina Moliner: carolina.moliner@gmail.com

\section{A. Teams}

The team number you will be assigned to and your team members' names and email addresses will be sent to you prior to the project by your course instructor. 


\section{B. Project assignment}

The project assignment is divided into three parts:

1. Getting to know each other.

2. Team project - preparing a PowerPoint training guide on a specific Organizational Psychology-related topic for an expatriate, who is going to do business in a foreign host country.

3. Presentation of key points on scheduled dates

\section{Getting to Know Each Other - first week}

The first week of the project should be devoted to achieving two objectives:

1. Coordinate first chat and schedule meeting times that are convenient to all team members to work on the project (take into account time differences and different holiday dates - see time table in the site).

2. Get to know your team members:

During the first chat you should:

- Interview each other - get to know your team members, their personal background, values beliefs, behavioral norms, and behavioral patterns. Please share with your team members what is important for you to know, in order to improve communication, work effectively, and learn the most out of the experience in the project.

- Send your personal photo or recognize each other in the class photos.

- Respond together to the 2 scenarios below, compare your answers with that of your teammates and try to understand together why certain team members responded to it in a certain way. Identify the similarities and differences.

- At the end of the chat, discuss what country you would like to work on for your team project. - see "team Project - step 1" for further instructions.

Please email me by noon 10/19 written communication of your discussion regarding the scenarios. (This is in essence a give-away of points). Only one printout per team is needed. Be sure to clearly identify who is "saying" what and provide the names of the U.S. partners in the document (one submission per team).

Also, summarize your "get to know each other" in the first slide of your presentation (see below).

Optional: Send to your team members 4 pictures that best represent your personal identity, what you value most.

Scenario 1

You are riding a car driven by a close friend. He hits a pedestrian. You know he was going at least 45 miles $(70 \mathrm{~km})$ per hour in an area of the city where the maximum speed 
is 30 miles $(50 \mathrm{~km})$ per hour. There are no witnesses. His lawyer says that if you testify under oath that he was only driving 30 miles $(50 \mathrm{~km})$ per hour it may save him from serious consequences.

What right has your friend to expect you to protect him?

A. My friend has a definite right as a friend to expect me to testify to the lower figure (30 miles or $50 \mathrm{~km}$ ).

B. He has some right as a friend to expect me to testify to the lower figure.

C. He has no right as a friend to expect me to testify to the lower figure.

\section{Scenario 2}

You are a newspaper journalist who writes a weekly review of new restaurants. A close friend of yours has sunk all her savings in a new restaurant. You have eaten there and you really think the restaurant is not good.

What right does your friend have to expect you to go easy on her restaurant in your review?
A. She has a definite right as a friend to expect me to go easy on her restaurant in my review.
B. She has no right as a friend to expect me to do this for her

\section{Team Project $(80 \%$ of grade)}

- Your assignment is to prepare a training guide for an expatriate on a specific, approved topic in Organizational Psychology, who is going to do business in a foreign host country. The guide should help the expatriate to adapt to the host culture, avoid misunderstandings, and manage effectively with respect to the chosen topic.

- The training guide will be in power point format (of $\sim 12-15$ slides). Teams will prepare one presentation for all team members, which will be presented by all team members, in each his/her own class at the end of the project, as will be coordinated with your class instructor.

Step 1: Agree on what country and what topic your team will work on. Your host country should be other than the countries of participating team members and other than countries that any team member has visited. For example, if a U.S. student is originally from Vietnam and another student in Spain has visited France, then you cannot choose Spain, USA, Vietnam, and France as your host country. The U.S. students have already considered topics. Students in Spain may choose to work with students due to their topic or they may renegotiate topics with their teammates and submit the topics for approval from Dr. Glazer. 
Since we hope to get a variety of host countries and topics, you must get confirmation for your choices from the Dr. Sharon Glazer (Sharon.glazer@sjsu.edu) before starting to work.

\section{Step 2: Preparing the Training Guide for Expatriates}

- The training guide should include 8 parts:

- Complete each part before moving to the next.

- The proportional grade for each part appears in $(\mathrm{X} \%)$ next to the description of each part.

Part 1: 1 slide (10\%)

Summary of the get to know each other from the first week: presenting the team and the team members.

Part 2: up to 4 slides $(15 \%)$

Introduce information about the dominant values, expectations, managerial practices and behaviors that are salient in the host culture, mainly in the workplace. The information should help the expatriate to adapt to the host culture, avoid misunderstandings, and manage effectively.

Part 3: 1 slide (5\%)

Cultural Value Differences between the host culture and team members' cultures: Compare the Host country and the team members' countries according to Hofstede, Schwartz, or House (GLOBE) value typologies.

This part should result in 1 table presenting the differences in values between the countries.

Part 4: 1 slide (5\%)

Focal Topic: Present basic information about the focal topic (e.g., definitions)

Part 5: 1-2 slides (15\%)

Analyze and discuss how expatriates from the team members' countries will adapt to the core managerial practices (i.e., the focal topic) presented in Parts $2 \& 4$.

Explain to what degree you expect difficulties in adaptation to the host country by the expatriates from the participating countries, using the value analysis in Part 3.

Use this part to learn about your culture as compared to the other team members' cultures in adapting to the host culture.

Part 6: 1 slide $(10 \%)$

Validation of the information you present: you must validate the information presented. To do so please (a) make sure the information you base on internet sites, is reliable and repeats in more then one source. (b) conduct a short interview, with a native of your host country, or someone who lived/worked there for a while and confirm your information. On the slide, summarize the interview. 
Part 7: 1 slide (10\%)

Summary of the training guide. Based on the above information and analyses make recommendations that will help the expatriates from the team members' countries to adapt to the host culture, with respect to the focal topic.

Part 8: 1 slide (10\%): Summarize the team process towards accomplishing its goals: Points of difficulties; means of resolving communication problems; and getting to accomplish the task.

\section{Submission and presentation of the team project ( $10 \%$ of grade):}

On November 25, 2009, the group project must be completed, including the overall presentation, which consists of the 8 parts described above. The presentations should be submitted to Dr. Glazer and Dr. Moliner via email attachment by midnight GMT November 25, 2009.

Due to language barriers, students in Spain may prefer to have more information on slides than is warranted by Anglo standards for presentation. Therefore, you will submit two PPT presentations. One will be the version your team decides to use for the presentation and the other will be the one you would deliver had the presentation been given by U.S.-based trainers. Should you and your other U.S-based teammate think that the version you worked on with your Spanish teammates fulfills the requirements, you are welcome to submit only the one presentation (no late or subsequent presentations will be accepted). Also starting Nov. 25th, students will deliver their presentations along with their teammates.

Class Presentation: (10\%)

All teams will present the same team presentation in their classes. Please prepare to talk no more than 12 minutes, leaving time ( 3 minutes) for discussion and questions.

Since the presentation time is short, you should focus on the comparisons in part 4 and on your conclusions and experience (parts 4 to 8 ).

Be ready to talk not only about the comparisons to your country, but also about the comparisons among other team members' countries.

\section{Important notes}

- Grade: your grade for each part as marked by (X\%) above, will be based on the depth of knowledge, depth of analysis and integration, clarity and coherence of the parts above. - Think well what information you include in each slide. Follow the rules of preparing presentations.

- Since presentations are graded based on what you submit, we can not see what you plan to say. Therefore, use the notes area of each slide for elaborating and explaining on topics you will talk about in the presentation but that do not appear on the slides themselves. 


\section{Project Evaluation by the participants ( $10 \%$ of grade).}

As part of your assignment you will be asked to evaluate the experience gained by this project, by filling out a questionnaire. For the U.S. students, the requirement is that they complete a peer evaluation (of their U.S. partners' performance only).

\section{Communication in the project}

Students communicate electronically.

At least one chat per week (for 4 weeks) required (emails should be more frequent); Chat room conversations should be archived.

CC: emails to professors.

Professors should have brief weekly discussions about progress and rectify problems as soon as they arise.

SKYPE is a wonderful resource.

Professors should carry a "debriefing" upon project completion if time permits

Students should create a google group session to communicate with your fellow classmates and to upload documents to share. Be sure to invite your course instructors so that they have access to your communication. The group name should be VAPTP1 VAPTP2 (the numbers refer to your team number).

\section{Communication among team members}

- Communication will be done in English.

- Chat room - each team must meet in the chat room at least once a week having all team members present.

- EMail - you are most welcome to use your email.

- You can use other means of communication like messengers, and programs that allow talking through the net like Skype. But, see documentation below....

\section{Documentation}

The communication in the chat-rooms is saved. Once you use other means of communication, you must keep documentation and verify that you submitted all of your communication by the end of the project.

- e-mails: When you use e-mails:

- CC: You must cc: Dr. Glazer and Dr. Moliner on all mails.

- Subject: Your team number should always appear in the subject of your mail. For example: "Subject: Team 11 - next meeting".

- When using messenger programs (like windows messenger - MSN), before closing the chat, save it, or copy all the text into a word file. In the file name, please note the team number and the date (for example: "team5 15-11-09.rtf") and send to the project coordinator.

Each team will receive feedback based on the documented communication at the end of the project. 


\section{Communication with project coordinator}

- Messages - messages may be sent to all teams. Please check your email messages frequently.

- If you need something specific from your professor, please indicate "for professor team X" in the "subject" space (replace team number for X), in order to verify your mail will be looked at.

\section{Timetable and Deliverables}

\begin{tabular}{|l|l|l|}
\hline \multicolumn{1}{|c|}{ Assignment } & \multicolumn{1}{c|}{ Beginning date } & \multicolumn{1}{c|}{ Submission / finish date } \\
\hline $\begin{array}{l}\text { Fill out introductory } \\
\text { questionnaires }\end{array}$ & & October 13 \\
\hline Get to know each other & October 13 & Oct. 19 \\
\hline Project assignment & October 21 & November 25, Midnight GMT \\
\hline $\begin{array}{l}\text { Impression Paper (for U.S. } \\
\text { students) }\end{array}$ & October 21 & December 14 \\
\hline $\begin{array}{l}\text { Fill out project/peer } \\
\text { evaluation }\end{array}$ & December 14 & December 16 \\
\hline
\end{tabular}

October 13-19: Students will respond to 2 scenarios and submit conversation transcript. This part should be done via Skype or another program that keeps track of students' responses. It should be typed discussion (not voice discussion). Discuss which countries you may consider working on (provide at least 3 countries in order of preference in order to have 13 unique countries). Discuss topic to focus on during the VAP (e.g., motivation, leadership, justice, commitment, stress, negotiations and teams).

Oct. 19: (a) Submit "getting to know you" transcript (this is a copy of the transcript showing the discussion that took place; it includes all students' names clearly written for instructor to read through). (b) Submit country options (3 options ranked) and topic options (if different from what has already been approved to my students) get approval of country choice and topic choice by Oct. 21 on country choice (a country none of the students has visited before).

Assignments are due by noon (CA time; 9pm in Spain) on Oct. 19.

October 21-Nov. 25: students will work together to prepare a training guide on the chosen topic for expatriates from Spain and USA going to the chosen "3rd country." For example, if the groups decided to work on the topic of leadership and the 3rd country is Jordan, then they would present some information (cultural background) about Jordan and a little background on focus within the topic of leadership and what their U.S. and Spanish expatriates need to know (i.e., take-home messages) about leadership in Jordan that may be the same or different from the USA and from Spain. 
Nov. 25: PowerPoint presentations due by midnight GMT (i.e., in CA November 24th at $4 \mathrm{pm}$ and in Spain Nov. 25 at 1am); presentations begin on November 25 during class time.

Nov. 25, 30, Dec. 2 Presentations are from 9-10:15am in CA (6-7:15pm in Spain).

Dec. 14: 7:45 or 8am-9:30am

Dec. 14: Students will submit final impression paper (individual papers U.S. students are required to submit).

IMPRESSION PAPER: Each student in the USA will write a paper summarizing his/her experience with the VAP. Included in the paper will be a summary of the project, including brief background about the partners, the theory the group focused on for their VAP project, evidence of a literature review that has helped shape students' presentation (i.e., cite sources in the paper), and your overall impression of this type of program for exposing students to a modified study abroad program. Do you feel that interacting with students halfway around the globe has helped you learn the material differently?

(Explain) What are pros and cons of having participated in this VAP? Why? How do you think your partners (from abroad) felt about their participation in this VAP? Why? Your paper is due 12/14/2009 (final exam day). The paper counts for $\underline{25 \%}$ of students' final course grade.

\section{Coordinating Time Differences}

There is a 9-hour time difference between California and Valencia. Valencia is 9 hours ahead. For example, October 130900 (i.e., 9am) in California is 1800 (i.e., 6pm) in Valencia. Midnight November 25 GMT is 1600 (or 4pm) in California on November 24 and 0100 or $1 \mathrm{am}$ in Valencia on November 25.

Please update each other of local holidays that may occur during the project.

You can use the link bellow to follow up and check the specific times in each country: http://www.timeanddate.com/worldclock/converter.html

Or http://www.timeanddate.com/worldclock/meeting.html to see what times are best for your chats.

\section{Have Fun!}




\section{Appendix B: VAP Pre-Assessment (Time 1) \\ Virtually Abroad Program Team Project \\ Questionnaire \\ Project of October-December 2009}

Instructions: Please print this page and mark your answers by clearly writing in your response or circling the answer that best represents your answer.
(1) Country (of course):
(2) Nationality:

(1) United States (Sharon Glazer)

(2) Spain (Carolina Moliner)

\begin{tabular}{|c|c|c|c|c|c|c|c|c|}
\hline & & 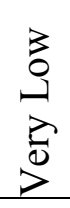 & 苂 & 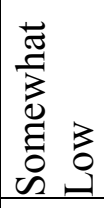 & $\begin{array}{l}\bar{\pi} \\
\tilde{E} \\
\overline{0}\end{array}$ & 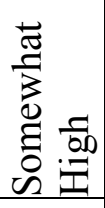 & 馬 & 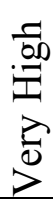 \\
\hline 1. & $\begin{array}{l}\text { My level of commitment to the } \\
\text { success of this project is... }\end{array}$ & 1 & 2 & 3 & 4 & 5 & 6 & 7 \\
\hline 2. & I intend to earn a grade that is.... & 1 & 2 & 3 & 4 & 5 & 6 & 7 \\
\hline
\end{tabular}

\begin{tabular}{|c|c|c|c|c|c|c|c|c|}
\hline \multicolumn{2}{|r|}{$\begin{array}{l}\text { To what extent do you agree or } \\
\text { disagree that the following descriptions } \\
\text { characterize you? Please mark the bes } \\
\text { fitting answer }\end{array}$} & 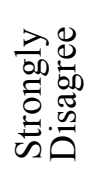 & 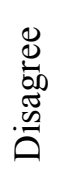 & 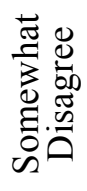 & 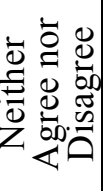 & 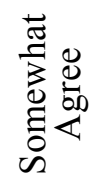 & 总 & 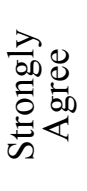 \\
\hline 1. & $\begin{array}{l}\text { I see myself as part of the global } \\
\text { international community. }\end{array}$ & 1 & 2 & 3 & 4 & 5 & 6 & 7 \\
\hline 2. & $\begin{array}{l}\text { I feel a strong attachment toward the } \\
\text { world environment to which I belong. }\end{array}$ & 1 & 2 & 3 & 4 & 5 & 6 & 7 \\
\hline 3. & $\begin{array}{l}\text { I would define myself as a citizen of } \\
\text { the global world. }\end{array}$ & 1 & 2 & 3 & 4 & 5 & 6 & 7 \\
\hline 4. & $\begin{array}{l}\text { I feel like I am a "next door } \\
\text { neighbour" of people from other parts } \\
\text { of the world. }\end{array}$ & 1 & 2 & 3 & 4 & 5 & 6 & 7 \\
\hline 5. & $\begin{array}{l}\text { I feel a strong attachment towards } \\
\text { people from all around the world. }\end{array}$ & 1 & 2 & 3 & 4 & 5 & 6 & 7 \\
\hline
\end{tabular}




\begin{tabular}{|c|c|c|c|c|c|c|c|c|}
\hline \multicolumn{2}{|r|}{$\begin{array}{l}\text { To what extent do you agree or } \\
\text { disagree that the following descriptions } \\
\text { characterize you? Please mark the best } \\
\text { fitting answer. }\end{array}$} & 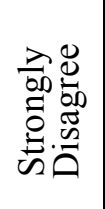 & 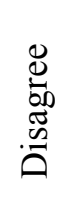 & 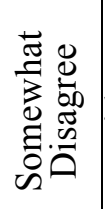 & 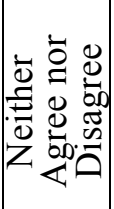 & 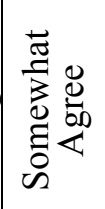 & 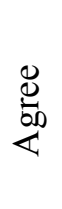 & 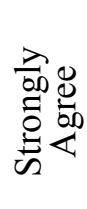 \\
\hline 6. & $\begin{array}{l}\text { I believe that my performance in } \\
\text { general life activities will improve as } \\
\text { a result of partaking in this virtually } \\
\text { abroad program team project. }\end{array}$ & 1 & 2 & 3 & 4 & 5 & 6 & 7 \\
\hline 7. & $\begin{array}{l}\text { I see myself as part of my home } \\
\text { society (e.g., Spain, America, Japan, } \\
\text { Morocco, etc.) }\end{array}$ & 1 & 2 & 3 & 4 & 5 & 6 & 7 \\
\hline 8. & $\begin{array}{l}\text { I feel a strong attachment towards the } \\
\text { society, to which I belong. }\end{array}$ & 1 & 2 & 3 & 4 & 5 & 6 & 7 \\
\hline 9. & $\begin{array}{l}\text { I define my self as a(n) } \quad \text { (your } \\
\text { nationality, e.g., Spaniard, American, } \\
\text { Japanese, etc.) }\end{array}$ & 1 & 2 & 3 & 4 & 5 & 6 & 7 \\
\hline 10. & $\begin{array}{l}\text { I feel like I am a "next door } \\
\text { neighbour" of people from my } \\
\text { country. }\end{array}$ & 1 & 2 & 3 & 4 & 5 & 6 & 7 \\
\hline 11. & $\begin{array}{l}\text { I feel a strong attachment towards } \\
\text { people from my country. }\end{array}$ & 1 & 2 & 3 & 4 & 5 & 6 & 7 \\
\hline 12. & $\begin{array}{l}\text { I feel that by partaking in this } \\
\text { virtually abroad program team } \\
\text { project, my approach to working with } \\
\text { people from different countries will } \\
\text { improve. }\end{array}$ & 1 & 2 & 3 & 4 & 5 & 6 & 7 \\
\hline 13. & $\begin{array}{l}\text { I often spend time with people from } \\
\text { cultural groups other than my own. }\end{array}$ & 1 & 2 & 3 & 4 & 5 & 6 & 7 \\
\hline 14. & $\begin{array}{l}\text { I enjoy doing jobs with people from } \\
\text { different ethnicity, gender, and/or } \\
\text { age. }\end{array}$ & 1 & 2 & 3 & 4 & 5 & 6 & 7 \\
\hline 15. & $\begin{array}{l}\text { I enjoy doing jobs with people whose } \\
\text { work values and/or motivations are } \\
\text { different. }\end{array}$ & 1 & 2 & 3 & 4 & 5 & 6 & 7 \\
\hline 16. & $\begin{array}{l}\text { I make an extra effort to listen to } \\
\text { people who hold different work } \\
\text { values and/or motivations. }\end{array}$ & 1 & 2 & 3 & 4 & 5 & 6 & 7 \\
\hline 17. & $\begin{array}{l}\text { I am keen to learn from people who } \\
\text { have different values or motivations. }\end{array}$ & 1 & 2 & 3 & 4 & 5 & 6 & 7 \\
\hline 18. & $\begin{array}{l}\text { I usually solve communication } \\
\text { problems that are caused by cultural } \\
\text { differences, easily. }\end{array}$ & 1 & 2 & 3 & 4 & 5 & 6 & 7 \\
\hline
\end{tabular}




\begin{tabular}{|c|c|c|c|c|c|c|c|c|}
\hline \multicolumn{2}{|r|}{$\begin{array}{r}\text { Please read each statement and select the } \\
\text { response that best describes your } \\
\text { capabilities AS YOU REALLY ARE } \\
\text { (1=strongly disagree; } 7=\text { strongly agree). } \\
\text { Note. National Culture refers to culture of a } \\
\text { country. }\end{array}$} & 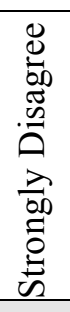 & 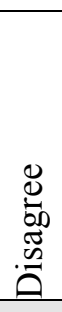 & 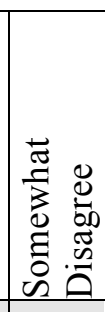 & 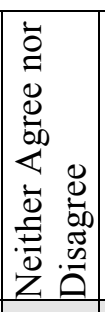 & 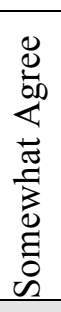 & 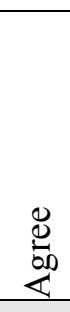 & 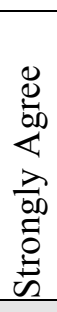 \\
\hline 1. & $\begin{array}{l}\text { I am conscious of the cultural knowledge I use } \\
\text { when interacting with people with different } \\
\text { national cultural backgrounds. }\end{array}$ & 1 & 2 & 3 & 4 & 5 & 6 & 7 \\
\hline 2. & $\begin{array}{l}\text { I am conscious of the national cultural } \\
\text { knowledge I apply to cross-cultural } \\
\text { interactions. }\end{array}$ & 1 & 2 & 3 & 4 & 5 & 6 & 7 \\
\hline 3. & $\begin{array}{l}\text { I adjust my cultural knowledge as I interact } \\
\text { with people from a national culture that is } \\
\text { unfamiliar to me. }\end{array}$ & 1 & 2 & 3 & 4 & 5 & 6 & 7 \\
\hline 4. & $\begin{array}{l}\text { I check the accuracy of my cultural knowledge } \\
\text { as I interact with people from different } \\
\text { cultures. }\end{array}$ & 1 & 2 & 3 & 4 & 5 & 6 & 7 \\
\hline 5. & $\begin{array}{l}\text { I know the legal and economic systems of } \\
\text { other national cultures. }\end{array}$ & 1 & 2 & 3 & 4 & 5 & 6 & 7 \\
\hline 6. & I know the religious beliefs of other cultures. & 1 & 2 & 3 & 4 & 5 & 6 & 7 \\
\hline 7. & I know the marriage systems of other cultures. & 1 & 2 & 3 & 4 & 5 & 6 & 7 \\
\hline 8. & I know the arts and crafts of other cultures. & 1 & 2 & 3 & 4 & 5 & 6 & 7 \\
\hline 9. & $\begin{array}{l}\text { I know the structural rules (e.g., grammar) of } \\
\text { other languages. }\end{array}$ & 1 & 2 & 3 & 4 & 5 & 6 & 7 \\
\hline 10 & $\begin{array}{l}\text { I know the rules for expressing non- } \mathrm{V} \\
\text { behaviours in other cultures. }\end{array}$ & 1 & 2 & 3 & 4 & 5 & 6 & 7 \\
\hline 11 & $\begin{array}{l}\text { I enjoy interacting with people from different } \\
\text { cultures. }\end{array}$ & 1 & 2 & 3 & 4 & 5 & 6 & 7 \\
\hline 12 & $\begin{array}{l}\text { I enjoy living in national cultures that are } \\
\text { unfamiliar to me. }\end{array}$ & 1 & 2 & 3 & 4 & 5 & 6 & 7 \\
\hline 13 & $\begin{array}{l}\text { I am confident that I can socialize with locals } \\
\text { in a national culture that is unfamiliar to me. }\end{array}$ & 1 & 2 & 3 & 4 & 5 & 6 & 7 \\
\hline
\end{tabular}




\begin{tabular}{|c|c|c|c|c|c|c|c|c|}
\hline \multicolumn{2}{|r|}{$\begin{array}{r}\text { Please read each statement and select the } \\
\text { response that best describes your } \\
\text { capabilities AS YOU REALLY ARE } \\
\text { (1=strongly disagree; } 7=\text { strongly agree). } \\
\text { Note. National Culture refers to culture of a } \\
\text { country. }\end{array}$} & 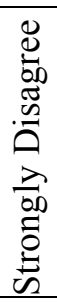 & 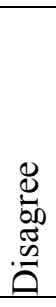 & 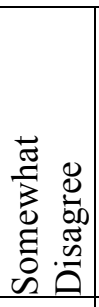 & 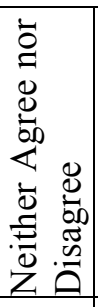 & 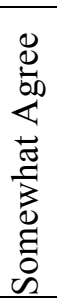 & $\begin{array}{l}\stackrel{ \pm}{ \pm} \\
\stackrel{50}{<} \\
\end{array}$ & 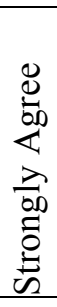 \\
\hline 14 & $\begin{array}{l}\text { I am confident that I can get accustomed to the } \\
\text { shopping conditions in a different culture. }\end{array}$ & 1 & 2 & 3 & 4 & 5 & 6 & 7 \\
\hline 15 & $\begin{array}{l}\text { I am sure I can deal with the stresses of } \\
\text { adjusting to a culture that is new to me. }\end{array}$ & 1 & 2 & 3 & 4 & 5 & 6 & 7 \\
\hline 16 & $\begin{array}{l}\text { I change my verbal behavior (e.g., accent, } \\
\text { tone) when a cross-cultural interaction } \\
\text { requires it. }\end{array}$ & 1 & 2 & 3 & 4 & 5 & 6 & 7 \\
\hline 17 & $\begin{array}{l}\text { I change my non-verbal behaviour when a } \\
\text { cross-cultural situation requires it. }\end{array}$ & 1 & 2 & 3 & 4 & 5 & 6 & 7 \\
\hline 18 & $\begin{array}{l}\text { I use pause and silence differently to suit } \\
\text { different cross-cultural situations. }\end{array}$ & 1 & 2 & 3 & 4 & 5 & 6 & 7 \\
\hline 19 & $\begin{array}{l}\text { I vary the rate of my speaking when a cross- } \\
\text { cultural situation requires it. }\end{array}$ & 1 & 2 & 3 & 4 & 5 & 6 & 7 \\
\hline 20 & $\begin{array}{l}\text { I alter my facial expressions when a cross- } \\
\text { cultural interaction requires it. }\end{array}$ & 1 & 2 & 3 & 4 & 5 & 6 & 7 \\
\hline 21 & $\begin{array}{l}\text { I get nervous when interacting with people of } \\
\text { a different national culture than mine. }\end{array}$ & 1 & 2 & 3 & 4 & 5 & 6 & 7 \\
\hline 22 & $\begin{array}{l}\text { I feel anxious about engaging in this virtually } \\
\text { abroad program team project. }\end{array}$ & 1 & 2 & 3 & 4 & 5 & 6 & 7 \\
\hline
\end{tabular}

\section{Thank You!!!}




\section{Appendix C: VAP Post-assessment (Time 2) \\ Virtual Abroad Program Team Project \\ Feedback Questionnaire \\ Project of October-December 2009}

\section{Instructions}

We hope you enjoyed your experience in the Virtual Abroad Program team project. The following questions mostly focus on your cross cultural team work processes. In the last section you will be asked to evaluate the project.

Please mark your answers by underlining or colouring them.

Before starting, please fill out the following information:

(1) ID letters (parents' first and last name initials):

(2) Country (of class):

(3) United States (Dr. Sharon Glazer)

(4) Spain (Dr. Carolina Moliner)

(3) Nationality:
(1) Spanish
(2) American
(3) Colombian
(4) German
(5) Romanian
(6) Belgian
(7) Dutch
(15)Other: (specify)

(8) Venezuelan

(9) Chinese

(10) Taiwanese

(11) Vietnamese

(12) Indian

(13) Japanese

(14) Fijian

(4) Sex (circle one):

1 Male 2 Female

(5) Age (as of November 1, 2009): years 


\section{Section 1: Team Processes}

\begin{tabular}{|c|c|c|c|c|c|c|c|c|}
\hline \multicolumn{2}{|r|}{ Part A1: Please mark the best fitting answer. } & \multicolumn{4}{|c|}{ 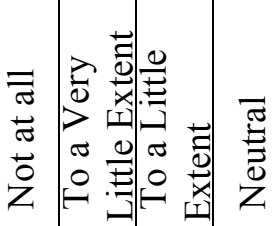 } & \multicolumn{2}{|c|}{ 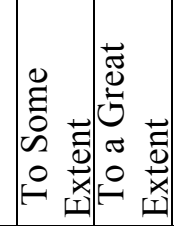 } & 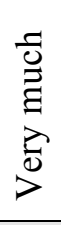 \\
\hline 1 & $\begin{array}{l}\text { How satisfied are you with overall team } \\
\text { performance? }\end{array}$ & 1 & 2 & 3 & 4 & 5 & 6 & 7 \\
\hline 2 & $\begin{array}{l}\text { To what extent were the team outcomes of high } \\
\text { quality? }\end{array}$ & 1 & 2 & 3 & 4 & 5 & 6 & 7 \\
\hline 3 & $\begin{array}{l}\text { To what extent were the team outcomes due to team } \\
\text { performance? }\end{array}$ & 1 & 2 & 3 & 4 & 5 & 6 & 7 \\
\hline 4 & $\begin{array}{l}\text { To what extent were the team outcomes influenced } \\
\text { by external constraints? }\end{array}$ & 1 & 2 & 3 & 4 & 5 & 6 & 7 \\
\hline 5 & $\begin{array}{l}\text { If the opportunity was presented, would you work } \\
\text { together again with your team? }\end{array}$ & 1 & 2 & 3 & 4 & 5 & 6 & 7 \\
\hline
\end{tabular}

Please indicate the level of commitment you and others in your team had to the success of this project:

\begin{tabular}{|c|c|c|c|c|c|c|c|c|}
\hline & & $\begin{array}{l}3 \\
\frac{3}{3} \\
\stackrel{3}{0} \\
>\end{array}$ & 䓵 & 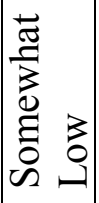 & 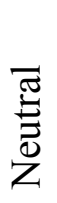 & 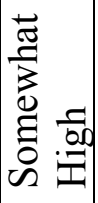 & 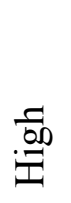 & $\begin{array}{l}\frac{0}{00} \\
\stackrel{0}{0} \\
\stackrel{0}{0}\end{array}$ \\
\hline 6 & My level of commitment was... & 1 & 2 & 3 & 4 & 5 & 6 & 7 \\
\hline 7 & Other team members' commitment was... & 1 & 2 & 3 & 4 & 5 & 6 & 7 \\
\hline 8 & I expect to earn a grade that is... & 1 & 2 & 3 & 4 & 5 & 6 & 7 \\
\hline
\end{tabular}




\section{Part A2: Please mark the best fitting answer.}

\begin{tabular}{|l|l|l|l|l|l|l|l|l|}
\hline Within the group I worked in... & Team members were willing to devote whatever \\
\hline $\mathbf{1}$ & 1 & 2 & 3 & 4 & 5 & 6 & 7 \\
\hline $\mathbf{2}$ & $\begin{array}{l}\text { Achort necessary to achieve team success. } \\
\text { than any individual objective. }\end{array}$ & 1 & 2 & 3 & 4 & 5 & 6 & 7 \\
\hline $\mathbf{3}$ & $\begin{array}{l}\text { The members of my group were cooperative } \\
\text { with each other }\end{array}$ & 1 & 2 & 3 & 4 & 5 & 6 & 7 \\
\hline $\mathbf{4}$ & $\begin{array}{l}\text { Everyone on the team seemed to work well } \\
\text { together }\end{array}$ & 1 & 2 & 3 & 4 & 5 & 6 & 7 \\
\hline $\mathbf{5}$ & $\begin{array}{l}\text { There were differences between group members } \\
\text { in the extent to which they shared information } \\
\text { with each other }\end{array}$ & 1 & 2 & 3 & 4 & 5 & 6 & 7 \\
\hline $\mathbf{6}$ & $\begin{array}{l}\text { There were differences between group members } \\
\text { in the extent to which they cooperated with each } \\
\text { other }\end{array}$ & 1 & 2 & 3 & 4 & 5 & 6 & 7 \\
\hline $\mathbf{7}$ & $\begin{array}{l}\text { There were group members who worked } \\
\text { individually and did not coordinate their work } \\
\text { with the group }\end{array}$ & 1 & 2 & 3 & 4 & 5 & 6 & 7 \\
\hline
\end{tabular}

\section{Part B: Please indicate the frequency in which the following situations occurred:}

In my team...

\begin{tabular}{|c|c|c|c|c|c|c|}
\hline 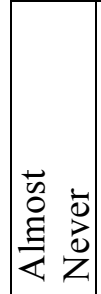 & $\mid \begin{array}{l}\frac{\lambda}{\vec{d}} \\
\bar{d} \\
\simeq\end{array}$ & 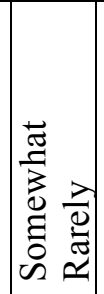 & 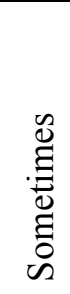 & 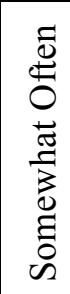 & 离 & 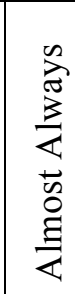 \\
\hline 1 & 2 & 3 & 4 & 5 & 6 & 7 \\
\hline
\end{tabular}




\begin{tabular}{|c|c|c|c|c|c|c|c|c|}
\hline \multicolumn{2}{|c|}{ In my team... } & \multirow{2}{*}{ 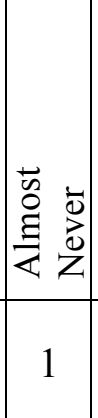 } & \multirow{2}{*}{ 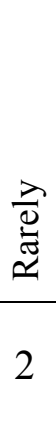 } & \multirow{2}{*}{ 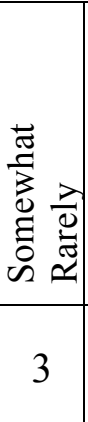 } & \multirow{2}{*}{ 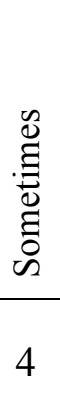 } & \multirow{2}{*}{ 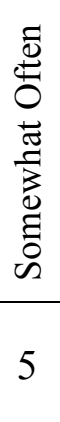 } & \multirow{2}{*}{ 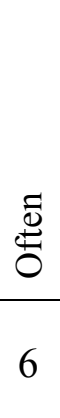 } & \multirow{2}{*}{ 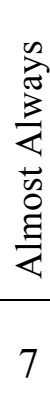 } \\
\hline 2 & $\begin{array}{l}\text { We listened to each other and considered each } \\
\text { others' opinions }\end{array}$ & & & & & & & \\
\hline 3 & We listened carefully to minority viewpoints & 1 & 2 & 3 & 4 & 5 & 6 & 7 \\
\hline 4 & We tried to get everyone's input & 1 & 2 & 3 & 4 & 5 & 6 & 7 \\
\hline 5 & $\begin{array}{l}\text { Some members had a difficult time being } \\
\text { listened to }\end{array}$ & 1 & 2 & 3 & 4 & 5 & 6 & 7 \\
\hline 6 & $\begin{array}{l}\text { Team members felt free to make negative } \\
\text { comments }\end{array}$ & 1 & 2 & 3 & 4 & 5 & 6 & 7 \\
\hline 7 & My team often reviewed its objectives & 1 & 2 & 3 & 4 & 5 & 6 & 7 \\
\hline 8 & $\begin{array}{l}\text { We regularly discussed whether the team was } \\
\text { working effectively }\end{array}$ & 1 & 2 & 3 & 4 & 5 & 6 & 7 \\
\hline 9 & $\begin{array}{l}\text { In our team we regularly discussed the flow of } \\
\text { information between us. }\end{array}$ & 1 & 2 & 3 & 4 & 5 & 6 & 7 \\
\hline 10 & $\begin{array}{l}\text { Team members were completely honest with } \\
\text { each other }\end{array}$ & 1 & 2 & 3 & 4 & 5 & 6 & 7 \\
\hline 11 & Team members could be trusted & 1 & 2 & 3 & 4 & 5 & 6 & 7 \\
\hline 12 & $\begin{array}{l}\text { Teams members took actions that were } \\
\text { consistent with their words }\end{array}$ & 1 & 2 & 3 & 4 & 5 & 6 & 7 \\
\hline 13 & Team members were reliable & 1 & 2 & 3 & 4 & 5 & 6 & 7 \\
\hline 14 & $\begin{array}{l}\text { I could rely on my team members to deliver } \\
\text { their parts as promised }\end{array}$ & 1 & 2 & 3 & 4 & 5 & 6 & 7 \\
\hline 15 & Everyone had a chance to participate & 1 & 2 & 3 & 4 & 5 & 6 & 7 \\
\hline 16 & $\begin{array}{l}\text { Team members were straight forward with each } \\
\text { other }\end{array}$ & 1 & 2 & 3 & 4 & 5 & 6 & 7 \\
\hline
\end{tabular}




\section{Part C1: For the following items, please mark the best fitting answer.}

\begin{tabular}{|c|c|c|c|c|c|c|c|c|}
\hline \multicolumn{2}{|c|}{ In my team... } & 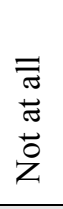 & 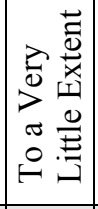 & 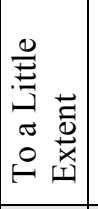 & $\begin{array}{l}\bar{\pi} \\
\stackrel{\bar{N}}{\bar{Z}} \\
\end{array}$ & 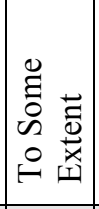 & 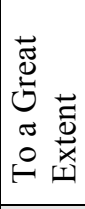 & 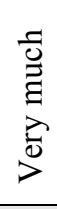 \\
\hline 1 & $\begin{array}{l}\text { How much did you trust your fellow group } \\
\text { members? }\end{array}$ & 1 & 2 & 3 & 4 & 5 & 6 & 7 \\
\hline 2 & $\begin{array}{l}\text { How comfortable did you feel delegating to } \\
\text { your group members? }\end{array}$ & 1 & 2 & 3 & 4 & 5 & 6 & 7 \\
\hline 3 & $\begin{array}{l}\text { Were your group members truthful and } \\
\text { honest? }\end{array}$ & 1 & 2 & 3 & 4 & 5 & 6 & 7 \\
\hline 4 & $\begin{array}{l}\text { How much do you respect your fellow group } \\
\text { members? }\end{array}$ & 1 & 2 & 3 & 4 & 5 & 6 & 7 \\
\hline 5 & $\begin{array}{l}\text { How much did you respect the ideas of the } \\
\text { people in your work group? }\end{array}$ & 1 & 2 & 3 & 4 & 5 & 6 & 7 \\
\hline 6 & How much do you like your group members? & 1 & 2 & 3 & 4 & 5 & 6 & 7 \\
\hline 7 & $\begin{array}{l}\text { To what degree would you consider these } \\
\text { people your friends? }\end{array}$ & 1 & 2 & 3 & 4 & 5 & 6 & 7 \\
\hline 8 & $\begin{array}{l}\text { How much open discussion of issues was there } \\
\text { in your work group? }\end{array}$ & 1 & 2 & 3 & 4 & 5 & 6 & 7 \\
\hline 9 & $\begin{array}{l}\text { To what degree was communication in your } \\
\text { group open? }\end{array}$ & 1 & 2 & 3 & 4 & 5 & 6 & 7 \\
\hline 10 & $\begin{array}{l}\text { To what degree was conflict dealt with openly } \\
\text { in your work group? }\end{array}$ & 1 & 2 & 3 & 4 & 5 & 6 & 7 \\
\hline 11 & $\begin{array}{l}\text { How much competition was there in your } \\
\text { work group? }\end{array}$ & 1 & 2 & 3 & 4 & 5 & 6 & 7 \\
\hline 12 & To what extent was your group cohesive? & 1 & 2 & 3 & 4 & 5 & 6 & 7 \\
\hline 13 & $\begin{array}{l}\text { How much do you feel like your team had } \\
\text { group spirit? }\end{array}$ & 1 & 2 & 3 & 4 & 5 & 6 & 7 \\
\hline 14 & $\begin{array}{l}\text { To what degree would you talk up this group } \\
\text { to your friends as a great group to work in? }\end{array}$ & 1 & 2 & 3 & 4 & 5 & 6 & 7 \\
\hline
\end{tabular}




\section{Part C2: For the following items, please mark the best fitting answer.}

\begin{tabular}{|c|c|c|c|c|c|c|c|c|}
\hline \multicolumn{2}{|c|}{ In my team... } & 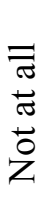 & 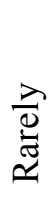 & 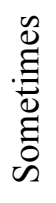 & $\underbrace{\bar{\Phi}}_{0}$ & 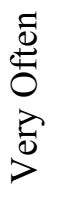 & 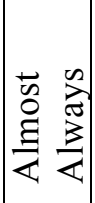 & $\frac{\sum_{i}^{\infty}}{\sum_{i}^{2}}$ \\
\hline 1 & $\begin{array}{l}\text { How much relationship tension was there in } \\
\text { your work group? }\end{array}$ & 1 & 2 & 3 & 4 & 5 & 6 & 7 \\
\hline 2 & $\begin{array}{l}\text { How often did people get angry while working } \\
\text { in your group? }\end{array}$ & 1 & 2 & 3 & 4 & 5 & 6 & 7 \\
\hline 3 & $\begin{array}{l}\text { How much emotional conflict was there in } \\
\text { your work group? }\end{array}$ & 1 & 2 & 3 & 4 & 5 & 6 & 7 \\
\hline 4 & $\begin{array}{l}\text { How much conflict of ideas was there in your } \\
\text { work group? }\end{array}$ & 1 & 2 & 3 & 4 & 5 & 6 & 7 \\
\hline 5 & $\begin{array}{l}\text { How often did you have disagreements within } \\
\text { your work group about the tasks of the project } \\
\text { you worked on? }\end{array}$ & 1 & 2 & 3 & 4 & 5 & 6 & 7 \\
\hline 6 & $\begin{array}{l}\text { How often did people in your work group have } \\
\text { conflicting opinions about the project you } \\
\text { were working on? }\end{array}$ & 1 & 2 & 3 & 4 & 5 & 6 & 7 \\
\hline 7 & $\begin{array}{l}\text { How often were there disagreements about } \\
\text { who should do what in your work group? }\end{array}$ & 1 & 2 & 3 & 4 & 5 & 6 & 7 \\
\hline 8 & $\begin{array}{l}\text { How much conflict was there in your work } \\
\text { group about task responsibilities? }\end{array}$ & 1 & 2 & 3 & 4 & 5 & 6 & 7 \\
\hline 9 & $\begin{array}{l}\text { How often did you disagree about resource } \\
\text { allocation in your work group? }\end{array}$ & 1 & 2 & 3 & 4 & 5 & 6 & 7 \\
\hline
\end{tabular}




\section{Part D}

In my team......

1 The overall level of conflict was...

\begin{tabular}{|c|c|c|c|c|c|c|}
\hline 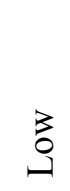 & 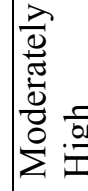 & 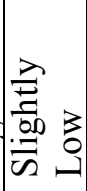 & 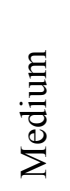 & 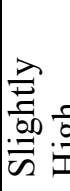 & 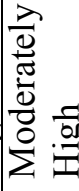 & $\frac{\overrightarrow{00}}{30}$ \\
\hline 1 & 2 & 3 & 4 & 5 & 6 & 7 \\
\hline
\end{tabular}

\begin{tabular}{|c|c|c|c|c|c|c|c|c|}
\hline \multicolumn{2}{|r|}{ In my team, conflict was mostly due to .... } & 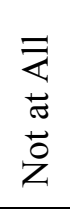 & 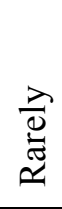 & 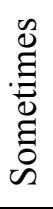 & 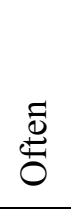 & 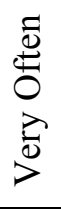 & 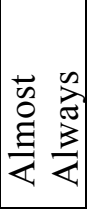 & $\begin{array}{l}\stackrel{n}{a} \\
\frac{3}{3} \\
\frac{\pi}{4}\end{array}$ \\
\hline 2 & misinterpretations or misunderstanding & 1 & 2 & 3 & 4 & 5 & 6 & 7 \\
\hline 3 & different means to achieve goals & 1 & 2 & 3 & 4 & 5 & 6 & 7 \\
\hline 4 & different goals or objectives & 1 & 2 & 3 & 4 & 5 & 6 & 7 \\
\hline 5 & different perspectives & 1 & 2 & 3 & 4 & 5 & 6 & 7 \\
\hline 6 & different behaviours & 1 & 2 & 3 & 4 & 5 & 6 & 7 \\
\hline 7 & different national cultures & 1 & 2 & 3 & 4 & 5 & 6 & 7 \\
\hline 8 & different values & 1 & 2 & 3 & 4 & 5 & 6 & 7 \\
\hline 9 & different personalities & 1 & 2 & 3 & 4 & 5 & 6 & 7 \\
\hline 10 & different gender (male/female) & 1 & 2 & 3 & 4 & 5 & 6 & 7 \\
\hline 11 & different levels of power/status & 1 & 2 & 3 & 4 & 5 & 6 & 7 \\
\hline 12 & different functions & 1 & 2 & 3 & 4 & 5 & 6 & 7 \\
\hline 13 & different ideas & 1 & 2 & 3 & 4 & 5 & 6 & 7 \\
\hline 14 & different education levels & 1 & 2 & 3 & 4 & 5 & 6 & 7 \\
\hline
\end{tabular}




\section{Part E: To what extent do you agree with the following statements? Please mark the best fitting answer.}

\begin{tabular}{|c|c|c|c|c|c|c|c|c|}
\hline & & 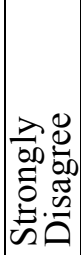 & 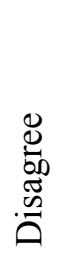 & 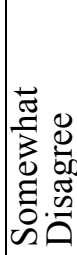 & 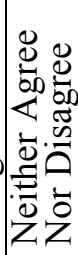 & 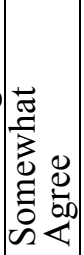 & 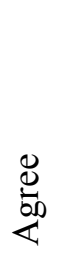 & 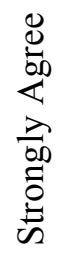 \\
\hline 1 & $\begin{array}{l}\text { There is one person in my team who took } \\
\text { responsibility for the schedule and communication } \\
\text { within the group }\end{array}$ & 1 & 2 & 3 & 4 & 5 & 6 & 7 \\
\hline 2 & $\begin{array}{l}\text { The same person organized the group's ideas and } \\
\text { tasks on the forum all the time }\end{array}$ & 1 & 2 & 3 & 4 & 5 & 6 & 7 \\
\hline 3 & $\begin{array}{l}\text { In my team there was a clearly identified team } \\
\text { leader. }\end{array}$ & 1 & 2 & 3 & 4 & 5 & 6 & 7 \\
\hline 4 & No member of my team dominates the discussion & 1 & 2 & 3 & 4 & 5 & 6 & 7 \\
\hline
\end{tabular}

Part F: For the next 2 questions, please indicate the overall feeling you had during the teamwork phase of the project.

\begin{tabular}{|ccccccc|}
\hline $\begin{array}{c}\mathbf{1} \\
\text { Very } \\
\text { negative }\end{array}$ & Negative & $\begin{array}{c}\mathbf{3} \\
\text { Slightly } \\
\text { negative }\end{array}$ & $\begin{array}{c}\mathbf{4} \\
\text { Both } \\
\text { negative } \\
\text { and } \\
\text { positive }\end{array}$ & $\begin{array}{c}\text { Slightly } \\
\text { positive }\end{array}$ & $\begin{array}{c}\mathbf{6} \\
\text { Positive }\end{array}$ & $\begin{array}{c}\text { Very } \\
\text { positive }\end{array}$ \\
\hline $\begin{array}{c}\mathbf{1} \\
\text { Low energy } \\
\text { (Apathy) }\end{array}$ & $\begin{array}{c}\text { Moderately } \\
\text { low energy }\end{array}$ & $\begin{array}{c}\text { Slightly low } \\
\text { energy }\end{array}$ & $\begin{array}{c}\text { Neutral } \\
\text { energy }\end{array}$ & $\begin{array}{c}\text { Slightly } \\
\text { high energy }\end{array}$ & $\begin{array}{c}\text { Moderately } \\
\text { high energy (Excitement) }\end{array}$ \\
\hline
\end{tabular}




\section{Section 2}

\section{Part A: To what extent do the following descriptions characterize you?}

Please mark the best fitting answer.

\begin{tabular}{|c|c|c|c|c|c|c|c|c|}
\hline & & 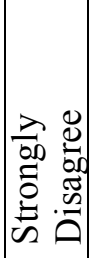 & 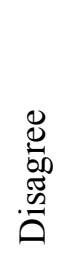 & 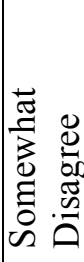 & 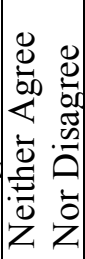 & 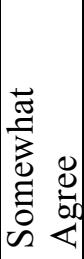 & 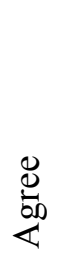 & 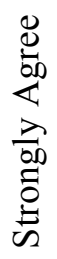 \\
\hline 19. & $\begin{array}{l}\text { I see myself as part of the global international } \\
\text { community }\end{array}$ & 1 & 2 & 3 & 4 & 5 & 6 & 7 \\
\hline 20. & $\begin{array}{l}\text { I feel a strong attachment toward the world } \\
\text { environment to which I belong }\end{array}$ & 1 & 2 & 3 & 4 & 5 & 6 & 7 \\
\hline 21. & $\begin{array}{l}\text { I would define myself as a citizen of the global } \\
\text { world }\end{array}$ & 1 & 2 & 3 & 4 & 5 & 6 & 7 \\
\hline 22. & $\begin{array}{l}\text { I feel like I am "next door neighbour" of people } \\
\text { from other parts of the world }\end{array}$ & 1 & 2 & 3 & 4 & 5 & 6 & 7 \\
\hline 23. & $\begin{array}{l}\text { I feel a strong attachment towards people from } \\
\text { all around the world. }\end{array}$ & 1 & 2 & 3 & 4 & 5 & 6 & 7 \\
\hline 24. & $\begin{array}{l}\text { I believe that my performance in general life } \\
\text { activities improved as a result of partaking in } \\
\text { this virtually abroad program team project. }\end{array}$ & 1 & 2 & 3 & 4 & 5 & 6 & 7 \\
\hline
\end{tabular}




\section{Part B: To what extent do the following descriptions characterize you? Please mark the best fitting answer.}

\begin{tabular}{|c|c|c|c|c|c|c|c|c|}
\hline & & 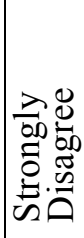 & 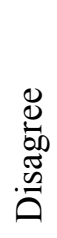 & 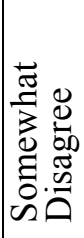 & 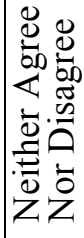 & 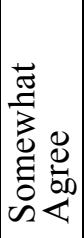 & 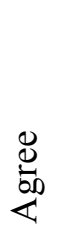 & 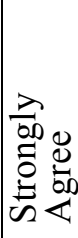 \\
\hline 1 & $\begin{array}{l}\text { I see myself as part of my society (e.g., Spain, } \\
\text { America, China, etc.) }\end{array}$ & 1 & 2 & 3 & 4 & 5 & 6 & 7 \\
\hline 2 & $\begin{array}{l}\text { I feel a strong attachment towards the society, to } \\
\text { which I belong. }\end{array}$ & 1 & 2 & 3 & 4 & 5 & 6 & 7 \\
\hline 3 & $\begin{array}{l}\text { I define my self as a(n) } \_ \text {(your nationality- } \\
\text { e.g., Spanish, American, Chinese, etc.) }\end{array}$ & 1 & 2 & 3 & 4 & 5 & 6 & 7 \\
\hline 4 & $\begin{array}{l}\text { I feel like I am "next door neighbour” of people } \\
\text { from my country }\end{array}$ & 1 & 2 & 3 & 4 & 5 & 6 & 7 \\
\hline 5 & $\begin{array}{l}\text { I feel a strong attachment towards people from } \\
\text { my country }\end{array}$ & 1 & 2 & 3 & 4 & 5 & 6 & 7 \\
\hline 6 & $\begin{array}{l}\text { I feel that by partaking in this virtually abroad } \\
\text { program team project, my approach to working } \\
\text { with people from different countries improved. }\end{array}$ & 1 & 2 & 3 & 4 & 5 & 6 & 7 \\
\hline
\end{tabular}

Part C: To what extent do the following statements describe you accurately?

\begin{tabular}{|c|c|c|c|c|c|c|c|c|}
\hline & & 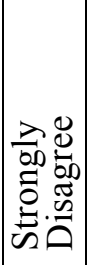 & 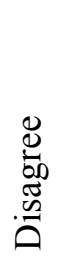 & 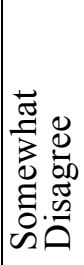 & 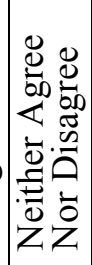 & 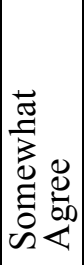 & 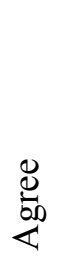 & 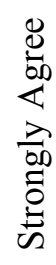 \\
\hline 1 & $\begin{array}{l}\text { I often spend time with people from cultural } \\
\text { groups other than my own }\end{array}$ & 1 & 2 & 3 & 4 & 5 & 6 & 7 \\
\hline 2 & $\begin{array}{l}\text { I enjoy doing jobs with people from different } \\
\text { ethnicity, gender, and/or age }\end{array}$ & 1 & 2 & 3 & 4 & 5 & 6 & 7 \\
\hline 3 & $\begin{array}{l}\text { I enjoy doing jobs with people whose work } \\
\text { values and/or motivations are different }\end{array}$ & 1 & 2 & 3 & 4 & 5 & 6 & 7 \\
\hline 4 & $\begin{array}{l}\text { I make an extra effort to listen to people who } \\
\text { hold different work values and/or motivations }\end{array}$ & 1 & 2 & 3 & 4 & 5 & 6 & 7 \\
\hline 5 & $\begin{array}{l}\text { I am keen to learn from people who have } \\
\text { different values or motivations }\end{array}$ & 1 & 2 & 3 & 4 & 5 & 6 & 7 \\
\hline
\end{tabular}




\begin{tabular}{|c|c|c|c|c|c|c|c|c|}
\hline & & 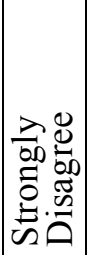 & 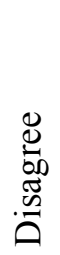 & 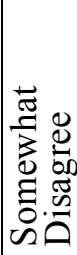 & 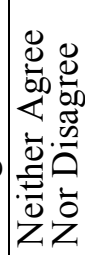 & 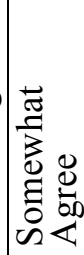 & 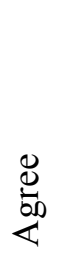 & 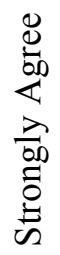 \\
\hline 6 & $\begin{array}{l}\text { I usually solve communication problems that are } \\
\text { caused by cultural differences, easily. }\end{array}$ & 1 & 2 & 3 & 4 & 5 & 6 & 7 \\
\hline
\end{tabular}

\section{Part D: Read each statement and select the response that best describes your capabilities. Select the answer that BEST describes you AS YOU REALLY ARE (1=strongly disagree; $7=$ =strongly agree)}

\begin{tabular}{|c|c|c|c|c|c|c|c|c|}
\hline & & 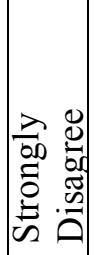 & 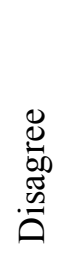 & 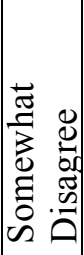 & 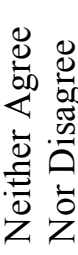 & 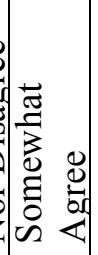 & 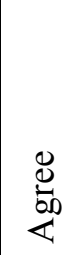 & 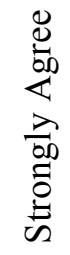 \\
\hline 1 & $\begin{array}{l}\text { I am conscious of the cultural knowledge I use } \\
\text { when interacting with people with different } \\
\text { cultural backgrounds }\end{array}$ & 1 & 2 & 3 & 4 & 5 & 6 & 7 \\
\hline 2 & $\begin{array}{l}\text { I am conscious of the cultural knowledge I apply } \\
\text { to cross-cultural interactions. }\end{array}$ & 1 & 2 & 3 & 4 & 5 & 6 & 7 \\
\hline 3 & $\begin{array}{l}\text { I adjust my cultural knowledge as I interact with } \\
\text { people from a culture that is unfamiliar to me. }\end{array}$ & 1 & 2 & 3 & 4 & 5 & 6 & 7 \\
\hline 4 & $\begin{array}{l}\text { I check the accuracy of my cultural knowledge as } \\
\text { I interact with people from different cultures. }\end{array}$ & 1 & 2 & 3 & 4 & 5 & 6 & 7 \\
\hline 5 & $\begin{array}{l}\text { I know the legal and economic systems of other } \\
\text { cultures. }\end{array}$ & 1 & 2 & 3 & 4 & 5 & 6 & 7 \\
\hline 6 & I know the religious beliefs of other cultures. & 1 & 2 & 3 & 4 & 5 & 6 & 7 \\
\hline 7 & I know the marriage systems of other cultures. & 1 & 2 & 3 & 4 & 5 & 6 & 7 \\
\hline 8 & I know the arts and crafts of other cultures. & 1 & 2 & 3 & 4 & 5 & 6 & 7 \\
\hline 9 & $\begin{array}{l}\text { I know the rules (e.g., grammar) of other } \\
\text { languages. }\end{array}$ & 1 & 2 & 3 & 4 & 5 & 6 & 7 \\
\hline 10 & $\begin{array}{l}\text { I know the rules for expressing non-verbal } \\
\text { behaviours in other cultures. }\end{array}$ & 1 & 2 & 3 & 4 & 5 & 6 & 7 \\
\hline 11 & $\begin{array}{l}\text { I enjoy interacting with people from different } \\
\text { cultures. }\end{array}$ & 1 & 2 & 3 & 4 & 5 & 6 & 7 \\
\hline
\end{tabular}




\begin{tabular}{|c|c|c|c|c|c|c|c|c|}
\hline & & 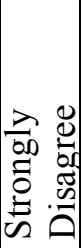 & 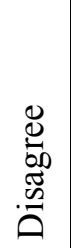 & 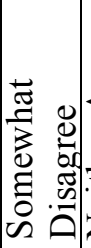 & 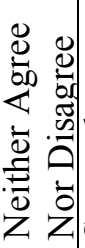 & 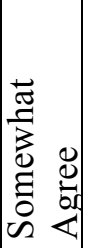 & 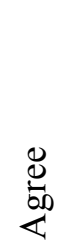 & 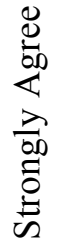 \\
\hline 12 & $\begin{array}{l}\text { I enjoy living in cultures that are unfamiliar to } \\
\text { me. }\end{array}$ & 1 & 2 & 3 & 4 & 5 & 6 & 7 \\
\hline 13 & $\begin{array}{l}\text { I am confident that I can socialize with locals in a } \\
\text { national culture that is unfamiliar to me. }\end{array}$ & 1 & 2 & 3 & 4 & 5 & 6 & 7 \\
\hline 14 & $\begin{array}{l}\text { I am confident that I can get accustomed to the } \\
\text { shopping conditions in a different culture. }\end{array}$ & 1 & 2 & 3 & 4 & 5 & 6 & 7 \\
\hline 15 & $\begin{array}{l}\text { I am sure I can deal with the stresses of adjusting } \\
\text { to a culture that is new to me. }\end{array}$ & 1 & 2 & 3 & 4 & 5 & 6 & 7 \\
\hline 16 & $\begin{array}{l}\text { I change my verbal behaviour (e.g., accent, tone) } \\
\text { when a cross-cultural interaction requires it. }\end{array}$ & 1 & 2 & 3 & 4 & 5 & 6 & 7 \\
\hline 17 & $\begin{array}{l}\text { I change my non-verbal behaviour when a cross- } \\
\text { cultural situation requires it. }\end{array}$ & 1 & 2 & 3 & 4 & 5 & 6 & 7 \\
\hline 18 & $\begin{array}{l}\text { I use pause and silence differently to suit different } \\
\text { cross-cultural situations }\end{array}$ & 1 & 2 & 3 & 4 & 5 & 6 & 7 \\
\hline 19 & $\begin{array}{l}\text { I vary the rate of my speaking when a cross- } \\
\text { cultural situation requires it. }\end{array}$ & 1 & 2 & 3 & 4 & 5 & 6 & 7 \\
\hline 20 & $\begin{array}{l}\text { I alter my facial expressions when a cross-cultural } \\
\text { interaction requires it. }\end{array}$ & 1 & 2 & 3 & 4 & 5 & 6 & 7 \\
\hline 21 & $\begin{array}{l}\text { I get nervous when interacting with people of a } \\
\text { different national culture than mine. }\end{array}$ & 1 & 2 & 3 & 4 & 5 & 6 & 7 \\
\hline 22 & $\begin{array}{l}\text { I felt anxious about engaging in this virtually } \\
\text { abroad program team project. }\end{array}$ & 1 & 2 & 3 & 4 & 5 & 6 & 7 \\
\hline
\end{tabular}




\section{Section 3 - Project evaluation}

We hope you enjoyed your participation in this international project. We would appreciate if you could answer a number of questions that will allow us to improve our project in following courses. Thank you.

Please indicate to what extent do you strongly disagree (1) or strongly agree (7) with the following statements

\begin{tabular}{|c|c|c|c|c|c|c|c|c|}
\hline & & 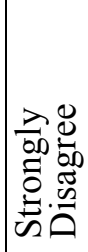 & 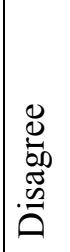 & 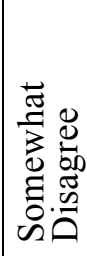 & 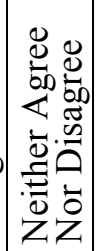 & 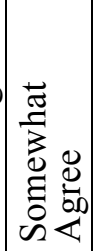 & 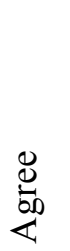 & 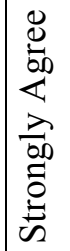 \\
\hline 1 & $\begin{array}{l}\text { I personally gained knowledge about other } \\
\text { cultures. }\end{array}$ & 1 & 2 & 3 & 4 & 5 & 6 & 7 \\
\hline 2 & $\begin{array}{l}\text { I learned from working with participants from } \\
\text { other cultures. }\end{array}$ & 1 & 2 & 3 & 4 & 5 & 6 & 7 \\
\hline 3 & $\begin{array}{l}\text { I learned how to work effectively with } \\
\text { members from other cultures. }\end{array}$ & 1 & 2 & 3 & 4 & 5 & 6 & 7 \\
\hline 4 & $\begin{array}{l}\text { The decision to participate in this project was a } \\
\text { huge mistake. }\end{array}$ & 1 & 2 & 3 & 4 & 5 & 6 & 7 \\
\hline 5 & $\begin{array}{l}\text { In my future job I want to be part of a virtual } \\
\text { team. }\end{array}$ & 1 & 2 & 3 & 4 & 5 & 6 & 7 \\
\hline 6 & $\begin{array}{l}\text { In my future job I want to be part of a multi } \\
\text { cultural team. }\end{array}$ & 1 & 2 & 3 & 4 & 5 & 6 & 7 \\
\hline 7 & $\begin{array}{l}\text { I dedicated a lot of my free time to work on this } \\
\text { project. }\end{array}$ & 1 & 2 & 3 & 4 & 5 & 6 & 7 \\
\hline 8 & $\begin{array}{l}\text { The interactions with my team were positive } \\
\text { and enriched me a lot. }\end{array}$ & 1 & 2 & 3 & 4 & 5 & 6 & 7 \\
\hline 9 & $\begin{array}{l}\text { The project we worked on was interesting and } \\
\text { challenging. }\end{array}$ & 1 & 2 & 3 & 4 & 5 & 6 & 7 \\
\hline
\end{tabular}




\begin{tabular}{|c|c|c|c|c|c|c|c|c|}
\hline & & 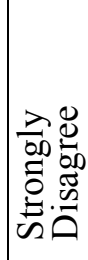 & 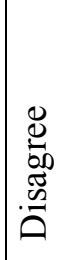 & 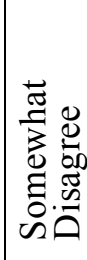 & 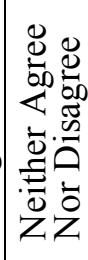 & 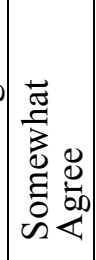 & 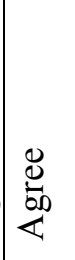 & 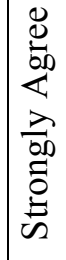 \\
\hline 10 & $\begin{array}{l}\text { I will recommend my friends to participate in } \\
\text { this project. }\end{array}$ & 1 & 2 & 3 & 4 & 5 & 6 & 7 \\
\hline 11 & $\begin{array}{l}\text { The project website provided all the support we } \\
\text { needed. }\end{array}$ & 1 & 2 & 3 & 4 & 5 & 6 & 7 \\
\hline 12 & $\begin{array}{l}\text { The instructions regarding communication were } \\
\text { clear. }\end{array}$ & 1 & 2 & 3 & 4 & 5 & 6 & 7 \\
\hline 13 & It was clear what were the project assignments. & 1 & 2 & 3 & 4 & 5 & 6 & 7 \\
\hline 14 & $\begin{array}{l}\text { I benefited from the individual feedback I } \\
\text { received at the beginning of the project. }\end{array}$ & 1 & 2 & 3 & 4 & 5 & 6 & 7 \\
\hline
\end{tabular}

Please answer the following questions:

1. How many hours (on average) did you work on the project each week?

2. What were the technical problems that you dealt with during your work?

3. What other difficulties emerged during your work? What were your means for coping with them (please elaborate)?

4. What means could have helped you to learn more out of the project? 
5. Please rate the extent to which you agree or disagree with the following statement.

This project contributed to my knowledge about cross-cultural/international work.

\begin{tabular}{|c|c|c|c|c|c|c|}
\hline $\begin{array}{c}\text { Strongly } \\
\text { Disagree }\end{array}$ & Disagree & $\begin{array}{c}\text { Somewhat } \\
\text { Disagree }\end{array}$ & $\begin{array}{c}\text { Neither } \\
\text { Agree nor } \\
\text { Disagree }\end{array}$ & $\begin{array}{c}\text { Somewhat } \\
\text { Agree }\end{array}$ & Agree & $\begin{array}{c}\text { Strongly } \\
\text { Agree }\end{array}$ \\
$\mathbf{1}$ & $\mathbf{2}$ & $\mathbf{3}$ & $\mathbf{4}$ & $\mathbf{5}$ & $\mathbf{6}$ & 7 \\
\hline
\end{tabular}

6. Please elaborate on what you have learned from participating in the project:

a.

b.

c.

7. Additional comments:

\section{Thank You!!!}

